\title{
The Effect of Green Tea on plaque and gingival inflammation: A systematic review
}

Gartenmann, Stefanie J ; Steppacher, Severine L ; von Weydlich, Yves ; Heumann, Christian ; Attin, Thomas ; Schmidlin, Patrick R

\begin{abstract}
Green tea has been shown in individual studies to be effective in reducing plaque and its use against gingivitis. Therefore, the aim of this study was to systematically review available literature on green tea catechin. The systematic literature search was performed using electronic databases in CINAHL, Cochrane Library, MEDLINE, PubMed and Scopus until January 2017. The PRISMA criteria were applied and a research question was posed according to PICO: "In patients with gingivitis (population), what is the effect of green tea catechinscontaining mouthwash (intervention and comparison) on plaque accumulation and gingival inflammation (outcome)?". Out of 187 titles identified by the search strategy, five were suitable for meta-analyses. These five studies were undertaken on a predominately Asian population. Plaque (PI) and Gingival Index (GI) were compared at endpoint and with respect to the change throughout the study (baseline-endpoint). The results from the metaanalysis indicated that green tea and chlorhexidine (CHX) resulted in lower PI compared to placebo while there was no significant difference between CHX and green tea, either at endpoint or over time. In addition, there was little evidence of side effects with green tea mouthwash. Green tea mouthwash may be a viable alternative to $\mathrm{CHX}$, especially for long-term use. However, due to the very heterogeneous data and the risk of bias, this evidence should be interpreted with caution. Further clinically controlled studies with a longer observation period are required.
\end{abstract}

DOI: https://doi.org/10.1016/j.hermed.2020.100337

Posted at the Zurich Open Repository and Archive, University of Zurich

ZORA URL: https://doi.org/10.5167/uzh-196168

Journal Article

Accepted Version

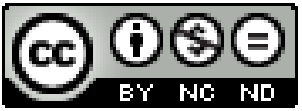

The following work is licensed under a Creative Commons: Attribution-NonCommercial-NoDerivatives 4.0 International (CC BY-NC-ND 4.0) License.

Originally published at:

Gartenmann, Stefanie J; Steppacher, Severine L; von Weydlich, Yves; Heumann, Christian; Attin, Thomas; Schmidlin, Patrick R (2020). The Effect of Green Tea on plaque and gingival inflammation: A systematic review. Journal of Herbal Medicine, 21:100337.

DOI: https://doi.org/10.1016/j.hermed.2020.100337 


\title{
The Effect of Green Tea on plaque and gingival inflammation: A systematic review
}

Stefanie J. Gartenmann ${ }^{a}$, Severine L. Steppacher ${ }^{\mathrm{b}}$, Yves von Weydlich ${ }^{\mathrm{b}}$, Christian Heumann ${ }^{c}$, Thomas Attin ${ }^{a}$, Patrick R. Schmidlina

${ }^{a}$ Clinic of Preventive Dentistry, Periodontology and Cariology, Center of Dental Medicine, University of Zurich, Zürich, Switzerland

bPrivate practices in Switzerland, Switzerland

'Department for Statistics, Ludwig-Maximilians-University Munich, Munich, Germany

\begin{abstract}
Green tea has been shown in individual studies to be effective in reducing plaque and against gingivitis. Therefore, the aim of this study was to to systematically review available literature on green tea catechin.

The systematic literature search was performed using electronic databases in CINAHL, Cochrane Library, MEDLINE, PubMed and Scopus until January 2017. The PRISMA criteria were applied and a research question was posed according to PICO: "In patients with gingivitis (population), what is the effect of green tea catechins-containing mouthwash (intervention and comparison) on plaque accumulation and gingival inflammation (outcome)?" Out of 187 titles identified by the search strategy, five were suitable for meta-analyses. These five studies were undertaken on a predominately Asian population. Plaque (PI) and Gingival Index ( $\mathrm{Gl}$ ) were compared at endpoint and with respect to the change throughout the study (baseline-endpoint). The results from the meta-analysis indicated that green tea and chlorhexidine (CHX) resulted in lower $\mathrm{PI}$ compared to placebo while there was no significant difference between $\mathrm{CHX}$ and green tea, either at endpoint or over time. In addition, there was little evidence of side effects with green tea mouthwash.

Green tea mouthwash may be a viable alternative to $\mathrm{CHX}$, especially for long-term use. However, due to the very heterogeneous data and the risk of bias, this evidence should be interpreted with caution. Further clinically controlled studies with a longer observation period are required.
\end{abstract}

\section{Introduction}

To prevent gingivitis, both mechanical plaque removal and chemical plaque control may be recommended. In particular, chemotherapeutics have the potential to inhibit plaque growth and reduce gingivitis (Supranoto et al., 2015). Due to a lack of compliance and manual dexterity a significant number of people do not achieve sufficient mechanical plaque removal and in turn benefit from adjunctive chemical usage (Axelsson and Lindhe, 1987; Baker, 1993; Christie et al., 1998). 
Therapeutic mouthwashes contains active ingredients that help control bad breath, plaque and gingivitis. Some of the most common therapeutic ingredients in mouthwash products are essential oils (EOs), cetyl pyridinium chloride (CPC) and chlorhexidine (CHX) (Araujo et al., 2015; Van der Weijden et al., 2015).

The anti-inflammatory effect of EO is based on its antioxidant activity, which has been shown to reduce plaque and gingival inflammation through plaque penetration (Haas et al., 2016; Ouhayoun, 2003; Van der Weijden et al., 2015). However, caution should be exercised when using alcohol-based mouthwashes since their use may cause pain and/or burning and may affect the connective tissue in the oral cavity (Poggi et al., 2003).

The cationic quaternary ammonium compound of CPC interacts with the cell membrane of bacteria, interrupting cell metabolism and inhibiting cell growth, followed by cell death as a consequence (Van der Weijden et al., 2015 ).

Of the chemical plaque control agents, $\mathrm{CHX}$ is the gold standard for the prevention of dental plaque (Axelsson and Lindhe, 1987; Van der Weijden et al., 2015). Years of documented research have demonstrated that chlorhexidine digluconate may prevent and control plaque formation, thereby inhibiting and reducing the development of gingivitis (Gunsolley, 2010; Loe, 1967). However, there are reports of side effects such as discoloration of the teeth, restorations and the tongue; increased formation of supragingival calculus and impairment of taste sensation. Occasionally, mucous membrane irritation and desquamation of the oral tissues have also been associated with the use of $\mathrm{CHX}$, especially with prolonged use (Van der Weijden et al., 2015).

Based on the reported side effects, alternative ingredients such as herbs or probiotics have gained in popularity and are the focus of attention in many research projects (Anand et al., 2015; Haffajee et al., 2008; Jockel-Schneider et al., 2016; Martin-Cabezas et al., 2016; Oliveira et al., 2017; Schlagenhauf et al., 2016). The search for alternative products and natural phytochemicals isolated from plants as used in herbal medicines is considered a good alternative to synthetic chemicals (Prabu et al., 2006). Especially for prolonged use and routine application, organic agents are desired as an alternative.

Among these natural phytochemicals, the health benefits of green teacatechins from the leaves of the plant Camellia sinensis have been shown to be beneficial in the treatment of a variety of diseases in Western medicine (Chacko et al., 2010; Khan and Mukhtar, 2007; McKay and Blumberg, 2002). The polyphenols in 
green tea have been found to contain bioactive ingredients with antioxidant properties that are useful in the treatment of chronic diseases (Khan and Mukhtar, 2007). The chemical composition of green tea polyphenols includes flavonols, flavandiole and phenolic acids. Most of the polyphenols are flavonols, also known as catechins (Chacko et al., 2010). These potent antioxidant catechins are epicatechin gallate (ECG), epicatechin (EC), epigallocatechin (EGC) and epigallocatechin-3-gallate (EGCG). EGCG has proven to be the most active catechin in green tea (Arab et al., 2011). The antioxidant, antimutagenic, anti-inflammatory, antiviral and antibacterial effect against gram positive bacteria of polyphenols are responsible for their health promoting effect (Chan et al., 2011; Hambire et al., 2015). Some studies have shown that polyphenols are able to inhibit the growth and adhesion of oral pathogens (Lombardo Bedran et al., 2014; Venkateswara et al., 2011).

However, little is known about the effect of green tea (as compared to $\mathrm{CHX}$ ) in the treatment of gingivitis. Therefore, the purpose of this systematic review is to answer the following PICO question: In patients with gingivitis does mouthwash containing green tea catechins have an effect on plaque accumulation and gingival inflammation?

\section{Methods}

The review considered the PRISMA checklist (Moher et al., 2015) and the focused question applied the criteria of the PICO method (Miller and Forrest).

\subsection{Literature search strategy and study selection}

The following electronic databases were reviewed up to January 2017: CINAHL, Cochrane Library, MEDLINE, PubMed and Scopus. The search was limited to human subjects, clinical trails, English and German language.

The following search terms were used (Appendix 1):

Population: "periodontal" OR "parodontal" AND "disease" OR "loss" OR "pocket" OR "pockets" OR "abscess" OR "pericementitis" OR "periodontoses" OR "periodontosis" OR "attachment" AND "loss" OR "clinical" OR "periodontal" OR "parodontal" AND "attachment"

Intervention: "camellia" AND "chinensis" OR "sinensis" OR "green tea" OR "epigallocatechin" OR "gallate" OR "gallic acid" OR "Veregen" OR "Exolise"

Two reviewers (SST and YvW) performed the primary search independently and screened the titles and abstracts for inclusion. The same reviewers selected the full 
manuscript of those studies meeting the inclusion criteria. Any disagreement was resolved by discussion with a third reviewer (SE).

\subsection{Inclusion and exclusion criteria}

Inclusion criteria for the present study was conform to PICO criteria (Miller and Forrest). Abstracts were considered if the following inclusion criteria were fulfilled.

Population: patients with gingivitis and good general health.

Intervention: the use of green tea extract in mouthwash.

Comparison: the control group contained either chlorhexidine gluconate or saline.

Outcome: plaque and gingival index (Loe, 1967; Loe and Silness, 1963) were recorded at the baseline and at the end of the trial.

Study design: randomized controlled clinical trials (RCT) or controlled clinical trails (CCT) with a minimum intervention time of 2 weeks with green tea mouthwash.

Studies were excluded for the following reasons: animal studies, in vitro studies, case reports, commentaries, only green tea and not a green tea extract was used, the study population suffered under a systemic disease (for example diabetes) (Appendix 2).

\subsection{Outcome measures}

The primary outcome measure to assess the efficacy of mouth rinse was the reduction of $\mathrm{PI}$ and $\mathrm{Gl}$ after the use of either a green tea or $\mathrm{CHX} /$ saline mouth rinse.

\subsection{Data extraction}

The following data for each study were extracted: number of subjects, chemical composition of the green tea extract (test), chemical composition of the control rinse (placebo or $\mathrm{CHX}$ ), study period, $\mathrm{PI}$ at baseline and study end and $\mathrm{GI}$ at baseline and study end.

\subsection{Data analysis and synthesis}

To compare and summarize the studies, data were extracted to calculate and analyze mean and standard deviation (SD) at baseline and study end with $95 \%$ confidence intervals (Cls). To compare the PI and GI values of the different studies, two types of meta-analysis were performed, analyzing the endpoint and changes over time. Forest plots were created to illustrate the effects of the different studies in the meta-analysis. The open source software $\mathrm{R}$ with the package "metafor" was used for a random effects analysis according to the method of DerSimonian and Laird (DerSimonian and Laird, 
1986). The statistical heterogeneity among the studies was assessed using the $Q$ test, according to chi-square statistics and the $I^{2}$ index $\left(l^{2}=25 \%\right.$ : low; $I^{2}=50 \%$ : moderate; $l^{2}=75 \%$ : high heterogeneity). The statistical significance was defined as a $p$-value < 0.05 .

\subsection{Assessment of risk of bias}

The studies of interest were evaluated for quality and risk of bias with a modified version of the Cochrane Collaboration's Tool (Graziani et al., 2012) (Appendix 2).

\section{Results}

\subsection{Study selection}

Initially, 187 studies were identified by electronic data search. Once the titles and abstracts were screened sixteen potentially relevant studies were subject to full text assessment. In the end, six studies fulfilled the inclusion criteria for the systematic review (Hambire et al., 2015; Priya et al., 2015; Radafshar et al., 2017; Rassameemasmaung et al., 2013; Sarin et al., 2015). The reasons for excluding the remaining studies are reported in Appendix 3 . Due to missing information and the presentation of PI and GI values only, the study of Jenabian and colleagues (Jenabian et al., 2012) was also excluded. Finally, five studies (Hambire et al., 2015; Priya et al., 2015; Radafshar et al., 2017; Rassameemasmaung et al., 2013; Sarin et al., 2015) were included for meta-analysis. An outline of the selection process is provided as in a flow-chart in Figure 1.

\subsection{Description of characteristics and results}

The methodological characteristics of the selected studies are depicted in Table 1. The study characteristics, relevant for the specific research question, are described as follows:

Population: The studies included were performed in India (Hambire et al., 2015; Priya et al., 2015; Sarin et al., 2015), Thailand (Rassameemasmaung et al., 2013) and Iran (Radafshar et al., 2017). The study by Hambire et al. (Hambire et al., 2015) investigated only children (9-14y old). All remaining studies defined the age range between 18-60 years. All studies included patients with gingivitis but no further "periodontal disease reported". Overall, a total of 300 subjects were evaluated in the meta-analysis. In detail 110 subjects participated in the study designed to receive 
saline as a negative control and 170 subjects were enrolled in the study distributing $\mathrm{CHX}$ in the control group.

Intervention/Comparison: Four (Hambire et al., 2015; Priya et al., 2015; Radafshar et al., 2017; Sarin et al., 2015) out of the five studies prepared a green tea solution by fragmenting dry leaves of Camellia sinensis. The final concentration was between 0.5$2 \%$ of green tea extract. Rassameemasmaung et al. (Rassameemasmaung et al., 2013) described a green tea extract containing more than $80 \%$ total catechins. Three studies (Hambire et al., 2015; Priya et al., 2015; Radafshar et al., 2017) used CHX as a (positive) control, whereas two studies (Rassameemasmaung et al., 2013; Sarin et al., 2015) chose to use normal saline or placebo for comparison. In four studies (Hambire et al., 2015; Radafshar et al., 2017; Sarin et al., 2015), the study population was instructed to rinse twice a day with $10-15 \mathrm{ml}$ for at least $60 \mathrm{~s}$. Priya and co-workers (Priya et al., 2015) mentioned the administration of verbal and written oral hygiene instructions but no rinse protocol was described. All patients were advised to follow their routine oral home care, using their usual toothbrush and toothpaste. Only participants from the study by Prjya et al. (Priya et al., 2015) were advised to use the modified bass technique. Study periods ranged from two to four weeks.

Outcome: All studies recorded PI (Loe, 1967) and GI (Loe and Silness, 1963) at baseline and at the end of examination. The endpoint for the study by Hambire et al. (Hambire et al., 2015) was 15 days, while all the other studies concluded after 28 days. Study design: All studies included a control group, which used either $\mathrm{CHX}$ (Hambire et al., 2015; Priya et al., 2015; Radafshar et al., 2017) or saline (Rassameemasmaung et al., 2013; Sarin et al., 2015). Three controlled clinical trails were double blinded (Hambire et al., 2015; Radafshar et al., 2017; Rassameemasmaung et al., 2013), one triple blinded (Sarin et al., 2015) and one single blinded (Priya et al., 2015).

\subsection{Outcome of the intervention on plaque index (PI) and gingival index (GI)}

In the present systematic review, plaque Index (PI) and gingival Index (GI) endpoint measurements were compared between test (green tea) and control ( $\mathrm{CHX}$ or placebo) groups. In addition, differences in changes between baseline and endpoint measurements for test and control groups were taken.

a) Plaque Index (PI): Test vs. $\mathrm{CHX}$ 
Three Studies (Hambire et al., 2015; Priya et al., 2015; Radafshar et al., 2017) measured PI after intervention with green tea or CHX mouth rinse (Priya et al., 2015; Radafshar et al., 2017). Two of the studies using CHX as a control agent started with a higher PI in the control group, except for the study conducted by Hambire et al. (Hambire et al., 2015), who showed close to identical values (Table 2a).

b) Plaque Index (PI): Test vs. Placebo

Two studies (Rassameemasmaung et al., 2013; Sarin et al., 2015) measured mean PI after intervention of green tea and placebo mouth rinse. At baseline both the intervention group as well as the control group showed similar values in PI but not at endpoint. The test group displayed slightly better values of $\mathrm{PI}$ than the control group but not statistically significant (Table $2 b$ ).

c) Gingival Index (GI): Test vs. CHX

Three Studies (Hambire et al., 2015; Priya et al., 2015; Radafshar et al., 2017) measured $\mathrm{Gl}$ after intervention of green tea or $\mathrm{CHX}$ mouth rinse (Table $3 \mathrm{a}$ ). Both the test and control group show similar GI values at baseline.

d) Gingival Index (GI): Test vs. Placebo

Two studies (Rassameemasmaung et al., 2013; Sarin et al., 2015) compared GI between the green tea group and the control (saline) group. Both groups started out with similar values for $\mathrm{Gl}$ (Table 3b). Overall, at the end of the interventions little change was seen in either the green tea or control group.

e) Meta-analysis PI

A meta- analysis was conducted to evaluate changes in $\mathrm{PI}$ at endpoint and over time. Further, a Forest plot was created to illustrate the data referenced in the meta- analysis (Table 4a-d). Overall the meta-analysis revealed no statistically significant changes between the test and $\mathrm{CHX}$ control groups, neither at endpoint nor over time (baseline - endpoint). Treatment modalities with a placebo (saline) also did not show any statistically significant data. With the exception of the study by Radafshar et al. (Radafshar et al., 2017), the Forest plot did show a tendency in favor of green tea, based on the data representing change over time. 
f) Meta-analysis GI

To evaluate changes in GI at endpoint and over time, a second meta-analysis was performed (Tables 5 a-d). Data of the meta-analysis showed neither statistically significant results in GI values at endpoint nor changes over time. A weak trend in favor of green tea could be observed in changes over time $(p=0.47,-0.03[-0.13,0.06] ; p=$ $0.33,-0.3[-0.94,0.31])($ Tables 5 c-d).

\section{g) Adverse-effects}

Four Studies (Hambire et al., 2015; Radafshar et al., 2017; Rassameemasmaung et al., 2013; Sarin et al., 2015) investigated adverse effects by questionnaire; none were reported. Unpleasant or altered taste and one single epithelium desquamation was reported by Radafshar and coworkers (Radafshar et al., 2017). Priya and colleagues (Priya et al., 2015) reported no statistical significance on tooth- or tongue stain.

\section{Discussion}

The present study evaluated the clinical efficacy of green tea containing mouthwash and its effect on plaque and gingival inflammation. Rinsing with green tea catechins resulted in a similar $\mathrm{PI}$ and $\mathrm{GI}$ as $\mathrm{CHX}$ or Placebo, without the side effects commonly experienced with $\mathrm{CHX}$ usage. The present systematic review included five randomized single and double-blinded controlled trials using green tea catechin containing mouthwash. Overall the data showed no statistically significant changes between the different mouthwash modalities used. However, the Forest plots illustrated a trend in favor of green tea. Hence, green tea mouthwash may be a good alternative to $\mathrm{CHX}$ as an adjunctive product in daily home care.

Axelsson and colleagues (Axelsson et al., 2004) have demonstrated that gingivitis can be effectively prevented and treated by well-performed mechanical oral hygiene, including tooth brushing in combination with interdental cleaning. Whereas mechanical means of plaque removal have gained widespread acceptance, it is interesting to examine the adjunctive benefits of chemotherapeutic mouthwash (Afennich et al., 2011). There is evidence that chemical agents can be effective against gingivitis. While mechanical plaque removal is considered to be the most effective means of removing biofilm from tooth surfaces (Jongsma et al., 2015), chemotherapeutic mouthwashes bear consideration for their ease of use, patient acceptance and ability to reach areas patients cannot always reach with their toothbrush or where tooth brushing may be 
contraindicated (ie. post-surgical sites). Although there are limitations in the efficacy of mouthwashes (e.g. inability to penetrate mature plaque), there is evidence that such chemotherapeutic solutions can be effective against gingivitis (Albert-Kiszely et al., 2007; Prasad et al., 2016; Sharma et al., 2004).

In today's Western population, mouthwash is accepted as adjunctive agent for prophylaxis and the battle against gingivitis, periodontal disease and caries. An increasing level of awareness about oral microbiology and plaque has led to the development of specific strategies, utilizing the antimicrobial effects of chemical substances (Afennich et al., 2011) Therefore, the requirement of an appropriate mouth rinse is that it contains antiseptic, antiplaque and anti-caries properties. In addition, mouth rinses with no (or just few minor) side effects are desired (Baker, 1993).

Chlorhexidine gluconate is considered the gold standard of antimicrobial mouthwash for the prevention of dental plaque formation (Axelsson and Lindhe, 1987). Compared to other antiseptics, $\mathrm{CHX}$ has been shown to be the most effective (Gjermo et al., 1970). The ability of $\mathrm{CHX}$ to reduce plaque formation and gingival inflammation was demonstrated in several systematic reviews (Gunsolley, 2010; Van Strydonck et al., 2012), and most recently by Serrano and colleagues (Serrano et al., 2015). Berchier et al. considered the clinical relevance of $0,2 \%$ versus $0.12 \% \mathrm{CHX}$ to be negligible (Berchier et al., 2010). Rinsing with $\mathrm{CHX}$ in addition to oral hygiene procedures results in approximately $33 \%$ less plaque and $26 \%$ less gingivitis as compared to controls (Van Strydonck et al., 2012). Gunsolley et al. evaluated $0.12 \% \mathrm{CHX}$ and achieved a mean GI reduction of $28,7 \%$ and a mean PI reduction of up to $40,4 \%$ (Gunsolley, 2010). However due to the side effects of $\mathrm{CHX}$, it is not recommended to use this agent for a prolonged time period (Supranoto et al., 2015; Van der Weijden et al., 2015; Van Strydonck et al., 2012). While reversible, local side effects such as staining and taste alteration are associated with long-term use of $\mathrm{CHX}$ mouth rinse (Supranoto et al., 2015). All these factors - to a varying degree - adversely affect patient compliance (Addy et al., 1995).

One of the shortcomings of this systematic review is the lack of uniformity in regards to the solutions employed in the control groups. Hence, the authors have chosen to separate both groups for evaluation of the meta-analysis. Nevertheless, the studies still revealed a high level of heterogeneity. The clinical protocol guidelines (ADA guidelines) demand statistically significant data in the reduction for both plaque and gingivitis. The present meta-analysis could not verify statistically significant data. An 
additional limitation is the short time frame of the studies examined, none of which fulfilled the 6-month requirement necessary for the ADA seal of acceptance in "Chemotherapeutic Products for Control of Gingivitis". A 6-month period is required to evaluate both the efficacy and safety of chemical agents as well as patients' compliance (https://www.ada.org/en/science-research/ada-seal-of-acceptance/howto-earn-the-ada-seal/general-criteria-for-acceptance).

The studies included in this systematic review advised all participants to follow their normal oral hygiene protocol. However as past studies have shown, daily use of a toothbrush may both prohibit gingival inflammation from occurring and if present, may lead to its reversal as a stand-alone measure (Loe et al., 1965). On this basis, the effectiveness of green tea as a mouth rinse agent may not be proven. In addition, all participants were very young, in good health, had no systemic diseases and predominately encompassed a population from India, Thailand and Iran. Therefore, further studies on diverse ethnic groups are recommended. This systematic review can be considered as a good beginning point for further reports on this product application. In summary, placebo-controlled randomized clinical trials with an expanded observation time of at least 6 months are recommended and necessary to determine the beneficial effects of green tea catechins on dental plaque and gingival inflammation.

\section{Conclusion}

It appears that Green tea may have an antiplaque and anti-gingivitis effect without causing side effects. Due to the highly heterogeneous data and the risk of bias, this evidence needs to be interpreted with caution. Further placebo controlled clinical trials with longer observation periods are needed.

\section{Conflict of interests}

The authors declare that there are no conflicts of interest.

\section{Acknowledgement}

The authors would like to acknowledge the work of Dr. S. Steppacher for her support in the analysis of the data as part of her master thesis. We also would like to thank our colleague D. Hofer from the Clinic of Preventive Dentistry, Periodontology and 
Cariology, Center of Dental Medicine, University of Zurich, Switzerland for proof reading the article.

\section{Funding sources}

This systematic review did not receive any grants from funding agencies or any outside sources.

\section{Appendix 1-3 and Supplementary data}

Supplementary data associated with this article can be found, in the online version 


\section{References}

Addy, M., Moran, J., Newcombe, R., Warren, P., 1995. The comparative tea staining potential of phenolic, chlorhexidine and anti-adhesive mouthrinses. Journal of clinical periodontology 22(12), 923-928.

Afennich, F., Slot, D.E., Hossainian, N., Van der Weijden, G.A., 2011. The effect of hexetidine mouthwash on the prevention of plaque and gingival inflammation: a systematic review. International journal of dental hygiene 9(3), 182-190.

Albert-Kiszely, A., Pjetursson, B.E., Salvi, G.E., Witt, J., Hamilton, A., Persson, G.R., Lang, N.P., 2007. Comparison of the effects of cetylpyridinium chloride with an essential oil mouth rinse on dental plaque and gingivitis - a six-month randomized controlled clinical trial. Journal of clinical periodontology 34(8), 658667.

Anand, G., Ravinanthan, M., Basaviah, R., Shetty, A.V., 2015. In vitro antimicrobial and cytotoxic effects of Anacardium occidentale and Mangifera indica in oral care. Journal of pharmacy \& bioallied sciences 7(1), 69-74.

Arab, H., Maroofian, A., Golestani, S., Sohrabi, K., Forouzanfar, A., 2011. Review of The therapeutic effects of Camellia sinensis (green tea) on oral and periodontal health. Journal of Medicinal Plants Research 5(23), 5465-5469.

Araujo, M.W., Charles, C.A., Weinstein, R.B., McGuire, J.A., Parikh-Das, A.M., Du, Q., Zhang, J., Berlin, J.A., Gunsolley, J.C., 2015. Meta-analysis of the effect of an essential oil-containing mouthrinse on gingivitis and plaque. Journal of the American Dental Association (1939) 146(8), 610-622.

Axelsson, P., Lindhe, J., 1987. Efficacy of mouthrinses in inhibiting dental plaque and gingivitis in man. Journal of clinical periodontology 14(4), 205-212.

Axelsson, P., Nystrom, B., Lindhe, J., 2004. The long-term effect of a plaque control program on tooth mortality, caries and periodontal disease in adults. Results after 30 years of maintenance. Journal of clinical periodontology 31(9), 749-757.

Baker, K., 1993. Mouthrinses in the prevention and treatment of periodontal disease. Current opinion in periodontology, 89-96.

Berchier, C.E., Slot, D.E., Van der Weijden, G.A., 2010. The efficacy of $0.12 \%$ chlorhexidine mouthrinse compared with $0.2 \%$ on plaque accumulation and periodontal parameters: a systematic review. Journal of clinical periodontology 37(9), 829-839.

Chan, E.W., Soh, E.Y., Tie, P.P., Law, Y.P., 2011. Antioxidant and antibacterial properties of green, black, and herbal teas of Camellia sinensis.

Pharmacognosy research 3(4), 266-272.

Christie, P., Claffey, N., Renvert, S., 1998. The use of $0.2 \%$ chlorhexidine in the absence of a structured mechanical regimen of oral hygiene following the nonsurgical treatment of periodontitis. Journal of clinical periodontology 25(1), $15-$ 23.

DerSimonian, R., Laird, N., 1986. Meta-analysis in clinical trials. Controlled clinical trials 7(3), 177-188.

Gjermo, P., Baastad, K.L., Rolla, G., 1970. The plaque=inhibiting capacity of 11 antibacterial compounds. Journal of periodontal research 5(2), 102-109.

Graziani, F., Figuero, E., Herrera, D., 2012. Systematic review of quality of reporting, outcome measurements and methods to study efficacy of preventive and therapeutic approaches to peri-implant diseases. Journal of clinical periodontology 39 Suppl 12, 224-244.

Gunsolley, J.C., 2010. Clinical efficacy of antimicrobial mouthrinses. Journal of dentistry 38 Suppl 1, S6-10. 
Haas, A.N., Wagner, T.P., Muniz, F.W., Fiorini, T., Cavagni, J., Celeste, R.K., 2016. Essential oils-containing mouthwashes for gingivitis and plaque: Meta-analyses and meta-regression. Journal of dentistry 55, 7-15.

Haffajee, A.D., Yaskell, T., Socransky, S.S., 2008. Antimicrobial effectiveness of an herbal mouthrinse compared with an essential oil and a chlorhexidine mouthrinse. Journal of the American Dental Association 139(5), 606-611.

Hambire, C.U., Jawade, R., Patil, A., Wani, V.R., Kulkarni, A.A., Nehete, P.B., 2015. Comparing the antiplaque efficacy of $0.5 \%$ Camellia sinensis extract, $0.05 \%$ sodium fluoride, and $0.2 \%$ chlorhexidine gluconate mouthwash in children. Journal of International Society of Preventive \& Community Dentistry 5(3), 218226.

https://http://www.ada.org/en/science-research/ada-seal-of-acceptance/how-to-earnthe-ada-seal/general-criteria-for-acceptance. November 2011

Jenabian, N., Moghadamnia, A.A., Karami, E., Mir, A.P., 2012. The effect of Camellia Sinensis (green tea) mouthwash on plaque-induced gingivitis: a single-blinded randomized controlled clinical trial. Daru : journal of Faculty of Pharmacy, Tehran University of Medical Sciences 20(1), 39.

Jockel-Schneider, Y., Gossner, S.K., Petersen, N., Stolzel, P., Hagele, F., Schweiggert, R.M., Haubitz, I., Eigenthaler, M., Carle, R., Schlagenhauf, U., 2016. Stimulation of the nitrate-nitrite-NO-metabolism by repeated lettuce juice consumption decreases gingival inflammation in periodontal recall patients: a randomized, double-blinded, placebo-controlled clinical trial. Journal of clinical periodontology 43(7), 603-608.

Jongsma, M.A., van de Lagemaat, M., Busscher, H.J., Geertsema-Doornbusch, G.I., Atema-Smit, J., van der Mei, H.C., Ren, Y., 2015. Synergy of brushing mode and antibacterial use on in vivo biofilm formation. Journal of dentistry 43(12), $1580-1586$.

Loe, H., 1967. The Gingival Index, the Plaque Index and the Retention Index Systems. Journal of periodontology 38(6), Suppl:610-616.

Loe, H., Silness, J., 1963. Periodontal Disease in Pregnancy. I. Prevalence and Severity. Acta odontologica Scandinavica 21, 533-551.

Loe, H., Theilade, E., Jensen, S.B., Schiott, C.R., 1967. Experimental gingivitis in man. 3. Influence of antibiotics on gingival plaque development. Journal of periodontal research 2(4), 282-289.

Lombardo Bedran, T.B., Feghali, K., Zhao, L., Palomari Spolidorio, D.M., Grenier, D., 2014. Green tea extract and its major constituent, epigallocatechin-3-gallate, induce epithelial beta-defensin secretion and prevent beta-defensin degradation by Porphyromonas gingivalis. Journal of periodontal research 49(5), 615-623.

Martin-Cabezas, R., Davideau, J.L., Tenenbaum, H., Huck, O., 2016. Clinical efficacy of probiotics as an adjunctive therapy to non-surgical periodontal treatment of chronic periodontitis: a systematic review and meta-analysis. Journal of clinical periodontology 43(6), 520-530.

Miller, S.A., Forrest, J.L., Enhancing your practice through evidence-based decision making: PICO, learning how to ask good questions. Journal of Evidence-Based Dental Practice 1(2), 136-141.

Moher, D., Shamseer, L., Clarke, M., Ghersi, D., Liberati, A., Petticrew, M., Shekelle, P., Stewart, L.A., Group, P.-P., 2015. Preferred reporting items for systematic review and meta-analysis protocols (PRISMA-P) 2015 statement. Systematic reviews 4,1 .

Oliveira, L.F., Salvador, S.L., Silva, P.H., Furlaneto, F.A., Figueiredo, L., Casarin, R., Ervolino, E., Palioto, D.B., Souza, S.L., Taba, M., Jr., Novaes, A.B., Jr., 
Messora, M.R., 2017. Benefits of Bifidobacterium animalis subsp. lactis Probiotic in Experimental Periodontitis. The Journal of periodontology 88(2), 197-208.

Ouhayoun, J.P., 2003. Penetrating the plaque biofilm: impact of essential oil mouthwash. Journal of clinical periodontology 30 Suppl 5, 10-12.

Poggi, P., Rodriguez y Baena, R., Rizzo, S., Rota, M.T., 2003. Mouthrinses with alcohol: cytotoxic effects on human gingival fibroblasts in vitro. Journal of periodontology 74(5), 623-629.

Prabu, G.R., Gnanamani, A., Sadulla, S., 2006. Guaijaverin -- a plant flavonoid as potential antiplaque agent against Streptococcus mutans. Journal of applied microbiology 101(2), 487-495.

Prasad, M., Patthi, B., Singla, A., Gupta, R., Jankiram, C., Kumar, J.K., Vashishtha, V., Malhi, R., 2016. The Clinical Effectiveness of Post-Brushing Rinsing in Reducing Plaque and Gingivitis: A Systematic Review. Journal of clinical and diagnostic research : JCDR 10(5), ZE01-07.

Priya, B.M., Anitha, V., Shanmugam, M., Ashwath, B., Sylva, S.D., Vigneshwari, S.K., 2015. Efficacy of chlorhexidine and green tea mouthwashes in the management of dental plaque-induced gingivitis: A comparative clinical study. Contemporary clinical dentistry 6(4), 505-509.

Radafshar, G., Ghotbizadeh, M., Saadat, F., Mirfarhadi, N., 2017. Effects of green tea (Camellia sinensis) mouthwash containing $1 \%$ tannin on dental plaque and chronic gingivitis: a double-blinded, randomized, controlled trial. Journal of investigative and clinical dentistry 8(1).

Rassameemasmaung, S., Phusudsawang, P., Sangalungkarn, V., 2013. Effect of green tea mouthwash on oral malodor. ISRN preventive medicine 2013, 975148.

Sarin, S., Marya, C., Nagpal, R., Oberoi, S.S., Rekhi, A., 2015. Preliminary Clinical Evidence of the Antiplaque, Antigingivitis Efficacy of a Mouthwash Containing 2\% Green Tea - A Randomised Clinical Trial. Oral health \& preventive dentistry 13(3), 197-203.

Schlagenhauf, U., Jakob, L., Eigenthaler, M., Segerer, S., Jockel-Schneider, Y., Rehn, M., 2016. Regular consumption of Lactobacillus reuteri-containing lozenges reduces pregnancy gingivitis: an RCT. Journal of clinical periodontology 43(11), 948-954.

Serrano, J., Escribano, M., Roldan, S., Martin, C., Herrera, D., 2015. Efficacy of adjunctive anti-plaque chemical agents in managing gingivitis: a systematic review and meta-analysis. Journal of clinical periodontology 42 Suppl 16, S106138.

Sharma, N., Charles, C.H., Lynch, M.C., Qaqish, J., McGuire, J.A., Galustians, J.G., Kumar, L.D., 2004. Adjunctive benefit of an essential oil-containing mouthrinse in reducing plaque and gingivitis in patients who brush and floss regularly: a sixmonth study. Journal of the American Dental Association 135(4), 496-504.

Supranoto, S.C., Slot, D.E., Addy, M., Van der Weijden, G.A., 2015. The effect of chlorhexidine dentifrice or gel versus chlorhexidine mouthwash on plaque, gingivitis, bleeding and tooth discoloration: a systematic review. International journal of dental hygiene 13(2), 83-92.

Venkateswara, B., Sirisha, K., Chava, V.K., 2011. Green tea extract for periodontal health. Journal of Indian Society of Periodontology 15(1), 18-22. 


\begin{tabular}{|c|c|c|}
\hline Step & Query & Hits \\
\hline 1 & $\begin{array}{l}\text { Search ((((((periodontal[tiab] OR parodontal[tiab] OR paradontal[tiab]) } \\
\text { AND } \\
\text { (disease[tiab] OR diseases[tiab] OR loss[tiab] OR pocket[tiab] OR } \\
\text { pockets[tiab] } \\
\text { OR abscess[tiab] OR abscesses[tiab] OR index[tiab])) OR } \\
\text { (pericementitides[tiab] } \\
\text { OR pericementitis[tiab] OR periodontitides[tiab] OR periodontitis[tiab] } \\
\text { OR } \\
\text { periodontoses[tiab] OR periodontosis[tiab] OR paradontitis[tiab] OR } \\
\text { parodontitis[tiab]) OR (attachment[tiab] AND loss[tiab]) OR } \\
\text { ((clinical[tiab] OR } \\
\text { periodontal[tiab] OR parodontal[tiab] OR paradontal[tiab]) AND } \\
\text { attachment[tiab])))) AND (((((camellia[tiab] AND (chinensis[tiab] OR } \\
\text { sinensis[tiab])) OR ("green tea"[tiab] OR epigallocatechin[tiab] OR } \\
\text { gallate[tiab] } \\
\text { OR "gallic acid"[tiab] OR Veregen[tiab] OR Exolise[tiab]))))) AND } \\
\text { (((inprocess[sb])) OR (publisher[sb] NOT pubstatusnihms NOT } \\
\text { pubstatuspmcsd } \\
\text { NOT pmcbook)) }\end{array}$ & 8 \\
\hline 2 & $\begin{array}{l}\text { Search ((inprocess[sb])) OR (publisher[sb] NOT pubstatusnihms NOT } \\
\text { pubstatuspmcsd NOT pmcbook) }\end{array}$ & 1077566 \\
\hline 3 & $\begin{array}{l}\text { Search (((((periodontal[tiab] OR parodontal[tiab] OR paradontal[tiab]) } \\
\text { AND } \\
\text { (disease[tiab] OR diseases[tiab] OR loss[tiab] OR pocket[tiab] OR } \\
\text { pockets[tiab] } \\
\text { OR abscess[tiab] OR abscesses[tiab] OR index[tiab])) OR } \\
\text { (pericementitides[tiab] } \\
\text { OR pericementitis[tiab] OR periodontitides[tiab] OR periodontitis[tiab] } \\
\text { OR } \\
\text { periodontoses[tiab] OR periodontosis[tiab] OR paradontitis[tiab] OR } \\
\text { parodontitis[tiab]) OR (attachment[tiab] AND loss[tiab]) OR } \\
\text { ((clinical[tiab] OR } \\
\text { periodontal[tiab] OR parodontal[tiab] OR paradontal[tiab]) AND } \\
\text { attachment[tiab])))) AND ((((camellia[tiab] AND (chinensis[tiab] OR } \\
\text { sinensis[tiab])) OR ("green tea"[tiab] OR epigallocatechin[tiab] OR } \\
\text { gallate[tiab] } \\
\text { OR "gallic acid"[tiab] OR Veregen[tiab] OR Exolise[tiab]))) }\end{array}$ & 57 \\
\hline 4 & $\begin{array}{l}\text { Search ((((camellia[tiab] AND (chinensis[tiab] OR sinensis[tiab])) OR } \\
\text { ("green tea" } \\
\text { [tiab] OR epigallocatechin[tiab] OR gallate[tiab] OR "gallic acid"[tiab] } \\
\text { OR } \\
\text { Veregen[tiab] OR Exolise[tiab])) }\end{array}$ & 14095 \\
\hline 5 & $\begin{array}{l}\text { Search (((periodontal[tiab] OR parodontal[tiab] OR paradontal[tiab]) } \\
\text { AND } \\
\text { (disease[tiab] OR diseases[tiab] OR loss[tiab] OR pocket[tiab] OR } \\
\text { pockets[tiab] }\end{array}$ & 49475 \\
\hline
\end{tabular}


OR abscess[tiab] OR abscesses[tiab] OR index[tiab])) OR (pericementitides[tiab]

OR pericementitis[tiab] OR periodontitides[tiab] OR periodontitis[tiab] OR periodontoses[tiab] OR periodontosis[tiab] OR paradontitis[tiab] ORparodontitis[tiab]) OR (attachment[tiab] AND loss[tiab]) OR ((clinical[tiab] OR periodontal[tiab] OR parodontal[tiab] OR paradontal[tiab]) AND attachment[tiab])) 
Appendix 3: Excluded studies

Excluded studies

Reason for exclusion

Sinija VR, Mishra HN. Green tea: health benefits. Journal of Nutritional \& Environmental Medicine. 2008;17(4):232-24211p.

Not addressing research question

Molina FD, Maniglia JV, Magalhaes FP, Dafico SR, Rezende RS. The efficacy of bismuth subgallate in tonsillectomy as hemostatic agent. Rev Bras Otorrinolaringol. 2000;66(3):194-197.

Not addressing research question

Magee K, Loiacono C. A review of common herbs and potential interactions. Int Not addressing J Dent Hygiene. 2004;2(3):111-12111p. research question

Lerman A, Lockwood B. Nutraceuticals in veterinary medicine.

PharmJ.2007;278(7434):51-55.

Not addressing

research question

Pavel L, Pavel S. [Usefulness of micronutrients in the treatment of periodontitis]. Ned Tijdschr Tandheelkd. 2010;117(2):103-106.

Full text assessment

Cravotto G, Boffa L, Genzini L, Garella D. Phytotherapeutics: an evaluation of the potential of 1000 plants. Journal of Clinical Pharmacy \& Therapeutics. 2010;35(1):11-4838p. doi:10.1111/j.1365-2710.2009.01096.x.

Not addressing research question

Priya BM, Anitha V, Shanmugam M, Ashwath B, Sylva SD, Vigneshwari SK. Efficacy of chlorhexidine and green tea mouthwashes in the management of dental plaque-induced gingivitis: A comparative clinical study. Contemp. 2015;6(4):505-509. doi:10.4103/0976-237X.169845.

Included study

Viana GSB, Menezes SMS, Cordeiro LN, Matos FJA. Biological effects of pomegranate (Punica granatum L.), especially its antibacterial actions, against microorganisms present in the dental plaque and other infectious processes. In: Bioactive Foods in Promoting Health. Elsevier Inc.; 2010:457-478. doi:10.1016/B978-0-12-374628-3.00031-1.

Not addressing research question

Isogai H, Isogai E, Takahashi K, Kurebayashi Y. Effect of catechin diet on gingivitis in cats. International Journal of Applied Research in Veterinary Medicine. 2008;6(2):82-86.

Animal study

Gurenlian JR, Spolarich AE. Risk assessment for clients with diabetes. Access. Not addressing 2010;24(6):32-354p.

research question

Jurenka J. Therapeutic applications of pomegranate (Punica granatum L.): a

Not addressing review. Alternative Medicine Review. 2008;13(2):128-14417p. research question

Lauten JD, Boyd L, Hanson MB, Lillie D, Gullion C, Madden TE. A clinical study: Melaleuca, Manuka, Calendula and green tea mouth rinse. Phytother Res. 2005;19(11):951-957.

Wang CY, Deng YT, Huang SY, Liu CM, Chang HH, Wong MY.

Not addressing research question

Epigallocatechin-3-gallate inhibits lysophosphatidic acid-stimulated connective tissue growth factor via JNK and Smad3 suppression in human gingival fibroblasts. J Formos Med Assoc. 2014;113(1):50-55. doi:10.1016/j.jfma.2012.04.004.

In vitro study

Hurd L. Publisher's notes. Total Health. 2006;27(6):6-61p.

Not addressing research question

Ravi K, Divyashree P. Psidium guajava: A review on its potential as an adjunct in treating periodontal disease. Pharmacogn Rev. 2014;8(16):96-100. doi:10.4103/0973-7847.134233.

Review

Funosas ER, Martinez AB, Pignolo M, et al. Efficacy of green tea in the treatment of chronic periodontitis. Av Odontoestomatol. 2005;21(3):159-166.

Full text assessment

Anonymous. Green tea and oral health examined in study. Br Dent J. 2010;208(9):384. doi:10.1038/sj.bdj.2010.436.

Not addressing research question 
Kozai K, Suzuki J, Okada M, Nagasaka N. Effect of oleanolic acid-cyclodextrin inclusion compounds on dental caries by in vitro experiment and rat-caries model. Microbios. 1999;97(388):179-188.

Animal study

Gardner EJ, Ruxton CHS, Leeds AR. Black tea - Helpful or harmful? A review of the evidence. Eur J Clin Nutr. 2007;61(1):3-18. doi:10.1038/sj.ejcn.1602489.

Review

5th Joint Meeting of the European Tissue Repair Society and the Wound

Not addressing Healing Society. Wound Repair \& Regeneration. 2009;17(4):A54-871p. research question

Ooshima T, Minami T, Aono W, et al. Oolong tea polyphenols inhibit experimental dental caries in spf rats infected with mutans streptococci. Caries Res. 1993;27(2):124-129. doi:10.1159/000261529.

Animal study

Not addressing

Strausfogel S. Dental care to smile about. Better Nutrition. 2007;69(2):42-421p. research question

Prithi R, Geetha RV. Static effects of fruits on periodontitis. Res J Pharm

Not addressing

Technol. 2014;7(3):365-367.

research question

Tomczyk M, Pleszczynska M, Wiater A. Variation in Total Polyphenolics

Contents of Aerial Parts of Potentilla Species and Their Anticariogenic Activity.

Molecules. 2010;15(7):4639-4651. doi:10.3390/molecules15074639.

In vitro study

Spratt DA, Daglia M, Papetti A, et al. Evaluation of Plant and Fungal Extracts for Their Potential Antigingivitis and Anticaries Activity. J Biomed Biotechnol. 2012:12. doi:10.1155/2012/510198.

Not addressing research question

Zagorouiko V, Mizin V, Bogadelnikov I, Ogay U. The Dietary Grape Polyphenol

Concentrate "ENOANT" Enables Protection Against Biological Agents. In:

Dishovsky C, Pivovarov A, eds. Counteraction to Chemical and Biological

Terrorism in East European Countries. Dordrecht: Springer; 2009:167-176. doi:10.1007/978-90-481-2342-1 21.

Not addressing research question

Signoretto C, Canepari P, Pruzzo C, Gazzani G. Woodhead Publ. Food Sci. Technol. Nutr. In: Wilson M, ed. Food Constituents and Oral Health: Current Status and Future Prospects. Cambridge: Woodhead Publ Ltd; 2009:240-262. doi:10.1533/9781845696290.2.240.

Not addressing research question

Subapriya R, Nagini S. Medicinal properties of neem leaves: A review. Curr Med Chem Anti-Cancer Agents. 2005;5(2):149-156. doi:10.2174/1568011053174828.

Not addressing research question

Belozerskaya GG, Makarov VA, Zhidkov EA, et al. Local hemostatics (A review). Pharm Chem J. 2006;40(7):353-359. doi:10.1007/s11094-006-0126-3.

Not addressing research question Pandit S, Song K-Y, Jeon J-G. Withania somnifera Attenuates Acid Production, Acid Tolerance and Extra-Cellular Polysaccharide Formation of Streptococcus mutans Biofilms. American Journal of Chinese Medicine. 2014;42(1):15717115p. doi:10.1142/S0192415X14500116.

Not addressing research question

Hamilton-Miller JMT. Anti-cariogenic properties of tea (Camellia sinensis). $J$ Not addressing Med Microbiol. 2001;50(4):299-302. research question

Choi $\mathrm{CH}$, Kim BI, Kwon HK, Hong SJ. Effects of herbal extracts on dental plaque formation and human gingival fibroblasts. In: Kim YH, Cho CS, Kang IK, Kim SY, Kwon OH, eds. ASBM7: Advanced Biomaterials VII. Vol 342-343. Stafa-Zurich: Trans Tech Publications Ltd; 2007:773-776.

In vitro

ASBM7: Advanced Biomaterials VII. Stafa-Zurich: Trans Tech Publications Ltd; Not addressing 2007. research question

Patel VK, Venkatakrishna-Bhatt $\mathrm{H}$. Folklore therapeutic indigenous plants in periodontal disorders in India (review, experimental and clinical approach). Int $J$ Not addressing Clin Pharmacol Ther Toxicol. 1988;26(4):176-184. research question

Corwin A, Zahorik L, Hurlbutt M. Herbal supplements: healthcare implications and considerations. Journal of the California Dental Hygienists' Association. 2009;24(2):7-159p.

Not addressing research question 
GREEN TEA BENEFITS. Explorer (08947929). 2015;41(1):2-21p.

Not addressing

Xu X, Zhou XD, Wu CD. Tea catechin epigallocatechin gallate inhibits

research question

Streptococcus mutans biofilm formation by suppressing gtf genes. Arch Oral

Biol. 2012;57(6):678-683. doi:10.1016/j.archoralbio.2011.10.021.

Not addressing

research question

Shanbhag VK. Triphala in prevention of dental caries and as an antimicrobial in oral cavity- A review. Infect Disord Drug Targets. 2015;15(2):89-97.

Not addressing

research question

Jaladat AM, Atarzadeh F, Rezaeizadeh $\mathrm{H}$, et al. Botanicals: An alternative remedy to radiotherapy-induced dysuria. Complement Ther Med.

2015;23(1):90-99. doi:10.1016/j.ctim.2014.11.004.

Not addressing

research question

Montbriand MJ. Herbs or natural products that increase cancer growth or recurrence: part two of a four-part series [corrected] [published erratum appears in ONCOL NURS FORUM 2006 Jul;33(4):684]. Oncology Nursing Forum. 2004;31(5):E99-1151p.

Not addressing

research question

Varoni EM, Lodi G, Sardella A, Carrassi A, Iriti M. Plant Polyphenols and Oral Health: Old Phytochemicals for New Fields. Current Medicinal Chemistry. 2012;19(11):1706-1720.

Not addressing

Logan El. Dietary Influences on Periodontal Health in Dogs and Cats. Vet Clin

research question

North Am Small Anim Pract. 2006;36(6):1385-1401.

doi:10.1016/j.cvsm.2006.09.002.

Not addressing

research question

Awadalla HI, Ragab MH, Fayed MT, Abbas MO, Bassuoni MW. Evaluation of

the effect of green tea on dental caries and composite restorations. TAF

Preventive Medicine Bulletin.

http://onlinelibrary. wiley.com/o/cochrane/clcentral/articles/483/CN-

00894483/frame.html. Published 2011. Accessed January 31, 2016.

Not addressing

research question

Soref A. A swish a day. Better Nutrition. 2006;68(2):46-461p.

Not addressing

research question

Makimura M, Hirasawa M, Kobayashi K, et al. Inhibitory effect of tea catechins

Not addressing

on collagenase activity. Journal of Periodontology. 1993;64(7):630-636.

research question

Williamson MP, Trevitt C, Noble JM. NMR-STUDIES OF DEXTRAN

OLIGOMER INTERACTIONS WITH MODEL POLYPHENOLS. Carbohydrate

Research. 1995;266(2):229-235. doi:10.1016/0008-6215(94)00273-i.

Not addressing

research question

Hattarki SA, Pushpa SP, Bhat K. Evaluation of the efficacy of green tea

catechins as an adjunct to scaling and root planing in the management of

chronic periodontitis using PCR analysis: A clinical and microbiological study. $J$

Not addressing

Indian Soc Periodontol. 2013;17(2):204-209. doi:10.4103/0972-124X.113071.

research question

Finkel J. In the news. Green tea may strengthen teeth. Life Extension.

2010;16(7):20-201p.

Not addressing

research question

Oberg E. Preconception counseling: helping patients plan for the future.

Not addressing

Integrative Medicine: A Clinician's Journal. 2009;8(4):46-494p.

research question

Yoo S, Murata RM, Duarte S. Antimicrobial Traits of Tea- and Cranberry-

Derived Polyphenols against Streptococcus mutans. Caries Res.

2011;45(4):327-335. doi:10.1159/000329181.

Not addressing

research question

Spratt DA, Daglia M, Papetti A, et al. Evaluation of Plant and Fungal Extracts for Their Potential Antigingivitis and Anticaries Activity. J Biomed Biotechnol. 2012;2012:1-1212p.

Daglia M, Papetti A, Mascherpa D, et al. Plant and Fungal Food Components

Not addressing research question

with Potential Activity on the Development of Microbial Oral Diseases. J Biomed

Not addressing

research question 
Biotechnol. 2011:1-99p.

Abebe W. Literature review. An overview of herbal supplement utilization with particular emphasis on possible interactions with dental drugs and oral manifestations. Journal of Dental Hygiene. 2003;77(1):37-4610p.

Not addressing

Consolini AE Ragone MI. Patterns of self-medication with medicinal plants and

related adverse events - A South American survey. Curr Drug Saf.

research question

2010;5(4):333-341. doi:10.2174/157488610792246019.

Cai LN, Wu CD. Compounds from Syzygium aromaticum possessing growth

inhibitory activity against oral pathogens. J NAT PROD. 1996;59(10):987-990.

doi:10.1021/np960451q

Not addressing

research question

Wojtaszek C. Management of chemotherapy-induced stomatitis. Clinical Journal Not addressing of Oncology Nursing. 2000;4(6):263-28210p.

research question

Ruxton C. Fluoride in the UK diet. Nursing Standard. 2014;28(49):52-598p. $\quad$ Not addressing doi:10.7748/ns.28.49.52.e9031.

research question

Krahwinkel T, Willershausen B. The effect of sugar-free green tea chew candies on the degree of inflammation of the gingiva. Eur J Med Res. 2000;5(11):463-

467.

Full text assessment

Homer KA, Manji F, Beighton D. Inhibition of protease activities of periodontopathic bacteria by extracts of plants used in Kenya as chewing sticks (mswaki). Arch Oral Biol. 1990;35(6):421-424. doi:10.1016/00039969(90)90203-M.

Not addressing research question

Radafshar G, Ghotbizadeh M, Saadat F, Mirfarhadi N. Effects of green tea (Camellia sinensis) mouthwash containing $1 \%$ tannin on dental plaque and chronic gingivitis: a double-blinded, randomized, controlled trial. J Investig Clin Dent. August 2017. doi:10.1111/jicd.12184.

Included study

Gadagi JS, Chava VK, Reddy VR. Green tea extract as a local drug therapy on periodontitis patients with diabetes mellitus: A randomized case-control study. $J$ Indian Soc Periodontol. 2013;17(2):198-203. doi:10.4103/0972-124X.113069.

Full text assessment

Strausfogel S. Gum health guide. Better Nutrition. 2008;70(11):32-342p.

Not addressing research question

Liu T, Chi Y. [Experimental study on polyphenol anti-plaque effect in human]. Chung Hua Kou Chiang Hsueh Tsa Chih. 2000;35(5):383-384.

Not addressing research question

News from The Journal of Chinese Medicine. Journal of Chinese Medicine. 2006;(81):67-737p.

Not addressing

research question

Awadalla HI, Ragab MH, Bassuoni MW, Fayed MT, Abbas MO. A pilot study of the role of green tea use on oral health. Int $J$ Dent Hygiene. 2011;9(2):110-116. doi:10.1111/j.1601-5037.2009.00440.x.

Full text assessment

Rivai H, Rina W, Rina DY, et al. Preparation and evaluation of herbal tea and toothpaste of mulberry leaves (Morus alba L.). Res J Pharm, Biol Chem Sci. 2015;6(4):1672-1677.

Not addressing research question

Abstracts. Alternative Medicine Review. 2006;11(3):244-26118p.

Not addressing research question

Sirois M, Darby M, Tolle S. Understanding Muslim patients: cross-cultural dental hygiene care. Int J Dent Hygiene. 2013;11(2):105-11410p. doi:10.1111/j.16015037.2012.00559.x.

Not addressing research question

Ready, set, shop. Better Nutrition. 2007;69(7):14-141p.

Not addressing research question 
Low SB, Peak RM, Smithson CW, Perrone J, Gaddis B, Kontogiorgos E.

Evaluation of a topical gel containing a novel combination of essential oils and antioxidants for reducing oral malodor in dogs. American Journal of Veterinary Research. 2014;75(7):653-657.

Animal study

Allaker RP, Douglas CWI. Novel anti-microbial therapies for dental plaquerelated diseases. International Journal of Antimicrobial Agents. 2009;33(1):8-13. Not addressing doi:10.1016/j.jantimicag.2008.07.014.

research question

Kaur H, Jain S, Kaur A. Comparative evaluation of the antiplaque effectiveness of green tea catechin mouthwash with chlorhexidine gluconate. J Indian Soc Periodontol. 2014;18(2):178-182. doi:10.4103/0972-124X.131320.

Full text assessment

Recently published abstracts. Alternative Medicine Review. 2010;15(4):36938012p.

Not addressing research question

Not addressing

Turner L. Indulge. Revive. Glow. Better Nutrition. 2011;73(4):31-4010p. research question

Hambire CU, Jawade R, Patil A, Wani VR, Kulkarni AA, Nehete PB. Comparing the antiplaque efficacy of $0.5 \%$ Camellia sinensis extract, $0.05 \%$ sodium fluoride, and $0.2 \%$ chlorhexidine gluconate mouthwash in children. J. 2015;5(3):218-226. doi:10.4103/2231-0762.158016. Included study

Hsu S-P, Liao C-S, Li C-Y, Chiou A-F. The effects of different oral care protocols on mucosal change in orally intubated patients from an intensive care unit. Journal of Clinical Nursing. 2011;20(7/8):1044-105310p. doi:10.1111/j.1365-2702.2010.03515.x.

Not addressing research question

Bedran TBL, Morin MP, Spolidorio DP, Grenier D. Black Tea Extract and Its Theaflavin Derivatives Inhibit the Growth of Periodontopathogens and Modulate Interleukin-8 and beta-Defensin Secretion in Oral Epithelial Cells. PLOS ONE. 2015;10(11):11. doi:10.1371/journal.pone.0143158.

Not addressing Rassameemasmaung S, Phusudsawang P, Sangalungkarn V. Effect of green tea mouthwash on oral malodor. ISRN Prev Med. 2013;2013:975148. doi:10.5402/2013/975148.

Included study

Spolarich AE, Andrews L. An examination of the bleeding complications associated with herbal supplements, antiplatelet and anticoagulant medications. Not addressing Journal of Dental Hygiene. 2007;81(3):67-671p. research question

Percival RS, Devine DA, Duggal MS, Chartron S, Marsh PD. The effect of cocoa polyphenols on the growth, metabolism, and biofilm formation by Streptococcus mutans and Streptococcus sanguinis. European Journal of Oral Sciences. 2006;114(4):343-348.

Sharafati-Chaleshtori R, Sharafati-Chaleshtori F, Rafieian M. Biological characterization of Iranian walnut (Juglans regia) leaves. Turkish Journal of Biology. 2011;35(5):635-639. doi:10.3906/biy-1005-1.

Wang RK, Zhao PP, Zhu B, Li JY. Inhibitive effect of extracts of Galla Chinesis Not addressing on caries development in rats. J Sichuan Univ Med Sci Ed. 2008;39(3):474-477. research question Shahakbari R, Eshghpour M, Rajaei A, Rezaei NM, Golfakhrabadi P, Nejat A. Effectiveness of green tea mouthwash in comparison to chlorhexidine mouthwash in patients with acute pericoronitis: a randomized clinical trial. International Journal of Oral \& Maxillofacial Surgery. 2014;43(11):1394-1398. doi:10.1016/j.jom.2014.05.017.

Not addressing research question

You SQ. [Study on feasibility of Chinese green tea polyphenols (CTP) for preventing dental caries]. Chung Hua Kou Chiang Hsueh Tsa Chih. 1993;28(4):197-9-254.

Not addressing research question Lingström P, Zaura E, Hassanö H, et al. The Anticaries Effect of a Food Extract (Shiitake) in a Short-Term Clinical Study. J Biomed Biotechnol. 2012;2012:11010p.

In vitro

Not addressing research question 
Kudva P, Tabasum ST, Shekhawat NK. Effect of green tea catechin, a local drug delivery system as an adjunct to scaling and root planing in chronic periodontitis patients: A clinicomicrobiological study. J Indian Soc Periodontol. 2011;15(1):39-45. doi:10.4103/0972-124X.82269.

Full text assessment

Chava VK, Vedula BD. Thermo-reversible green tea catechin gel for local application in chronic periodontitis: a 4-week clinical trial. Journal of Periodontology. 2013;84(9):1290-1296. doi:10.1902/jop.2012.120425.

Not addressing research question

Gowda DV, Muguli G, Rangesh PR, Deshpande RD. Phytochemical and pharmacological actions of triphala: Ayurvedic formulation - A review. Intl $J$ Pharm Sci Rev Res. 2012;15(2):61-65.

Not addressing research question

Paar WD, Bergmann Von K. Pharmacokinetics and toxicity of bismuth Not addressing compound. VERDAUUNGSKRANKHEITEN. 1992;10(4):140-143. research question Greenway FL, Liu Z, Martin CK, et al. Safety and efficacy of NT, an herbal supplement, in treating human obesity. International journal of obesity (2005). doi:10.1038/sj.ijo.0803343.

Not addressing research question

Ooshima T, Osaka Y, Sasaki H, et al. Caries inhibitory activity of cacao bean husk extract in in-vitro and animal experiments. Arch Oral Biol. 2000;45(8):639645. doi:10.1016/s0003-9969(00)00042-x.

In vitro stdy

Sariozlu NY, Kivanc M. Gallnuts (Quercus infectoria Oliv. and Rhus chinensis Mill.) and Their Usage in Health. In: Nuts and Seeds in Health and Disease Prevention. Elsevier Inc.; 2011:505-511. doi:10.1016/B978-0-12-3756886.10060-X.

Not addressing research question

Nuts and Seeds in Health and Disease Prevention. Elsevier Inc.; 2011. Not addressing research question Isogai $\mathrm{E}$, Isogai $\mathrm{H}$, Kimura $\mathrm{K}$, Nishikawa $\mathrm{T}$, Fujii N, Benno Y. EFFECT OF JAPANESE GREEN TEA EXTRACT ON CANINE PERIODONTAL-DISEASES. Not addressing Microbial Ecology in Health and Disease. 1995;8(2):57-61. research question

Wood N. Oral health -- how to reduce risks of periodontitis. Positive Health. Not addressing 2006;(127):30-356p. research question

Kushiyama M, Shimazaki Y, Murakami M, Yamashita Y. Relationship between intake of green tea and periodontal disease. Journal of Periodontology. 2009;80(3):372-377. doi:10.1902/jop.2009.080510.

Sah AK, Verma VK. Syzygium cumini: An overview. J Chem Pharm Res. 2011;3(3):108-113.

Full text assessment

\section{GREEN TEA FIGHTS ORAL CANCER. Better Nutrition. 2015;77(4):14-} $141 \mathrm{p}$.

Not addressing research question

Not addressing research question

Hirasawa M, Takada K, Makimura M, Otake S. Improvement of periodontal status by green tea catechin using a local delivery system: a clinical pilot study. J Periodontal Res. 2002;37(6):433-438.

Rattanasuwan K, Rassameemasmaung S, Sangalungkarn V, Komoltri C. Clinical effect of locally delivered gel containing green tea extract as an adjunct to non-surgical periodontal treatment. Odontology. 2016;104(1):89-97. doi:10.1007/s10266-014-0190-1.

Not addressing research question

Wyganowska-ŚWịitkowska M, Surdacka A, Skrzypczak-Jankun E, Jankun J. The plasminogen activation system in periodontal tissue (Review). Int $\mathrm{J} \mathrm{Mol}$ Med. 2014;33(4):763-768. doi:10.3892/ijmm.2014.1653.

Not addressing research question

Signoretto C, Burlacchini G, Bianchi F, Cavalleri G, Canepari P. Differences in microbiological composition of saliva and dental plaque in subjects with different drinking habits. New Microbiologica. 2006;29(4):293-302.

Not addressing research question 
Daglia M, Papetti A, Mascherpa D, et al. Plant and fungal food components with potential activity on the development of microbial oral diseases. J Biomed

Not addressing

Biotechnol. 2011;2011. doi:10.1155/2011/274578.

research question

Slikkerveer A, de Wolff FA. Pharmacokinetics and Toxicity of Bismuth

Compounds. Med Toxicol Adverse Drug Exp. 1989;4(5):303-323.

doi:10.1007/BF03259915.

Gutierrez-Venegas G, Ventura-Arroyo JA, Arreguin-Cano JA, Ostoa-Perez MF.

Flavonoids inhibit iNOS production via mitogen activated proteins in lipoteichoic acid stimulated cardiomyoblasts. Int Immunopharmacol. 2014;21(2):320-327.

doi:10.1016/j.intimp2014.04.010.

In vitro study

Smullen J, Finney M, Storey DM, Foster HA. Prevention of artificial dental plaque formation in vitro by plant extracts. J Appl Microbiol. 2012;113(4):964973. doi:10.1111/j.1365-2672.2012.05380.x.

Not addressing

research question

Recent abstracts. Alternative Medicine Review. 2008;13(1):65-8218p.

Not addressing

research question

Sebastian J, Tresch D. Use of oral anticoagulants in older patients. Drugs \&

Aging. 2000;16(6):409-43527p.

full text assessment

Niloofar J, Ali AM, Elaheh K, Poorsattar BMA. The effect of Camellia Sinensis

(green tea) mouthwash on plaque-induced gingivitis: a single-blinded

randomized controlled clinical trial. Daru. 2012;20:6. doi:10.1186/2008-2231-20-

39.

Full text assessment

Yiannakopoulou EC. Recent patents on antibacterial, antifungal and antiviral properties of tea. Recent Pat Anti-Infect Drug Discov. 2012;7(1):60-65. doi:10.2174/157489112799829738.

Not addressing

research question

Abstracts: recently published abstracts. Alternative Medicine Review. 2005;10(4):344-36320p.

Not addressing research question

Not addressing research question

Kiefer D. Disease prevention begins in the mouth. Life Extension.

Not addressing 2008;14(9):28-3710p.

research question

Sakagami H. Biological activities and possible dental application of three major groups of polyphenols. J Pharmacol Sci. 2014;126(2):92-106.

Not addressing doi:10.1254/jphs.14R04CR.

research question

Lakshmi T, Roy A, Geetha RV. "Acacia catechu willd -a gift from ayurveda to mankind" -a review. Pharma Res. 2011;5(2):273-293.

Not addressing

research question

Chang HS, Hwang HJ, Kang EH, et al. The effect of green tea bag in dogs with periodontal disease. J Vet Clin. 2009;26(1):41-47.

Animal study

Homer KA, Manji F, Beighton D. Inhibition of peptidase and glycosidase

activities of Porphyromonas gingivalis, Bacteroides intermedius and Treponema

denticola by plant extracts. Journal of Clinical Periodontology. 1992;19(5):305-

310.

In vitro study

Walker WA, Martens EC, Sherman PM, Lampe JW, Hullar MAJ, Wu CD.

Functional foods for health promotion: microbes and health: extended abstracts

from the 11th Annual Conference on Functional Foods for Health Promotion,

April 2008. Nutrition Reviews. 2009;67(1):40-489p.

Not addressing

Shen CL, Yeh JK, Cao JJ, Chyu MC, Wang JS. Green tea and bone health:

Evidence from laboratory studies. Pharmacol Res. 2011;64(2):155-161.

doi:10.1016/j.phrs.2011.03.012.

research question

Krahwinkel T, Stannarious M, Willershausen B. Efficacy of sugar-free green tea

drops on the clinical course of gingival inflammation [abstract]. International

dental journal.

http://onlinelibrary.wiley.com/o/cochrane/clcentral/articles/521/CN-

00793521/frame.html. Published 2000. Accessed January 31, 2016.

Not addressing

research question

Spolarich AE. Pharmacology. Managing clients taking medications for weight

loss. Access. 2002;16(5):48-523p.

Not addressing

research question 
Jenabian N, Moghadamnia AA, Karami E, Mir AP. The effect of Camellia Sinensis (green tea) mouthwash on plaque-induced gingivitis: a single-blinded randomized controlled clinical trial. Daru. 2012;20(1):39. doi:10.1186/20082231-20-39.

Full text assessment

Hsu SP, Liao CS, Li CY, Chiou AF. The effects of different oral care protocols on mucosal change in orally intubated patients from an intensive care unit. $J$ Clin Nurs. 2011;20(7-8):1044-1053. doi:10.1111/j.1365-2702.2010.03515.x.

Not addressing research question

Asif HM, Akram M, Uddin S, et al. Myrtus communis linn. (Pharmacological activity). J Med Plant Res. 2011;5(26):6257-6259. doi:10.5897/JMPR11.250.

Not addressing research question

Vervelle A, Mouhyi J, Del Corso M, Hippolyte M-P, Sammartino G, Dohan Ehrenfest DM. [Mouthwash solutions with microencapsuled natural extracts: Efficiency for dental plaque and gingivitis]. Rev Stomatol Chir Maxillofac. 2010;111(3):148-151. doi:10.1016/j.stomax.2009.09.014.

Not addressing research question

Sarin S, Marya C, Nagpal R, Oberoi SS, Rekhi A. Preliminary Clinical Evidence of the Antiplaque, Antigingivitis Efficacy of a Mouthwash Containing $2 \%$ Green Tea - A Randomised Clinical Trial. Oral health prev. 2015;13(3):197-203. doi:10.3290/j.ohpd.a33447.

Included study

Barilla J. Longevity. Healthy gums, healthy body: your gums are the key to a healthy smile, and more. Better Nutrition. 2000;62(3):24-262p.

Not addressing research question

Wolinsky LE, Cuomo J, Quesada K, Bato T, Camargo PM. A Comparative Pilot Study of the Effects of a Dentifrice Containing Green Tea Bioflavonoids, Sanguinarine or Triclosan on Oral Bacterial Biofilm Formation. J Clin Dent. 2000;11(2):53-59.

Not addressing research question

Dadashi M, Eslami G, Ranjbar F, et al. EVALUATION OF ANTIMICROBIAL ACTIVITY OF GREEN TEA EXTRACT ON BACTERIA ISOLATED FROM DENTAL PLAQUE. Iranian Journal of Public Health. 2014;43:308-308.

Not addressing research question

Mann C. Off the shelf: food. Tea: a cup full of health and happiness. Better Not addressing Nutrition. 2007;69(3):58-613p. research question

Smullen J, Koutsou GA, Foster HA, Zumbe A, Storey DM. The antibacterial activity of plant extracts containing polyphenols against Streptococcus mutans. Caries Res. 2007;41(5):342-349. doi:10.1159/000104791.

Tsuchiya $\mathrm{H}$, Sato $\mathrm{M}$, linuma $\mathrm{M}$, et al. INHIBITION OF THE GROWTH OF CARIOGENIC BACTERIA IN-VITRO BY PLANT FLAVANONES. Experientia. 1994;50(9):846-849. doi:10.1007/bf01956469.

Not addressing research question

Not addressing research question

Not addressing

News flash. Better Nutrition. 2009;71(6):10-112p. research question

Lombardo Bedran TB, Palomari Spolidorio D, Grenier D. Green tea polyphenol epigallocatechin-3-gallate and cranberry proanthocyanidins act in synergy with cathelicidin (LL-37) to reduce the LPS-induced inflammatory response in a three-dimensional co-culture model of gingival epithelial cells and fibroblasts. Arch Oral Biol. 2015;60(6):845-853. doi:10.1016/j.archoralbio.2015.02.021. Soltani R, Haghighat A, Fanaei M, Asghari G. Evaluation of the effect of green tea extract on the prevention of gingival bleeding after posterior mandibular teeth extraction: a randomized controlled trial. Evid Based Complement Alternat Med. 2014;2014:857651. doi:10.1155/2014/857651.

Hrishi T, Kundapur P, Naha A, Thomas B, Kamath S, Bhat G. Effect of adjunctive use of green tea dentifrice in periodontitis patients - A Randomized Controlled Pilot Study. Int J Dent Hygiene. 2015. doi:10.1111/idh.12131.

In vitro study

Not addressing research question

Not addressing research question 
Signoretto C, Canepari P, Stauder M, Vezzulli L, Pruzzo C. Functional foods and strategies contrasting bacterial adhesion. Current Opinion in Biotechnology. Not addressing 2012;23(2):160-167. doi:10.1016/j.copbio.2011.08.006. research question

Arab H, Maroofian A, Golestani S, Shafaee H, Sohrabi K, Forouzanfar A. Review of the therapeutic effects of Camellia sinensis (green tea) on oral and periodontal health. J Med Plant Res. 2011;5(23):5465-5469.

Oli MW, Otoo HN, Crowley PJ, et al. Functional amyloid formation by Streptococcus mutans. Microbiology. 2012;158(Pt 12):2903-2916. doi:10.1099/mic.0.060855-0.

Review

Kukreja BJ, Dodwad V. Herbal mouthwashes - A gift of nature. Intl J Pharma Bio Sci. 2012;3(2):P46-P52. Tamura M, Saito H, Kikuchi K, et al. Antimicrobial Activity of Gel-Entrapped
Catechins toward Oral Microorganisms. Biol Pharm Bull. 2011;34(5):638-643.

Not addressing research question

Not addressing research question Not addressing research question

Kemoli AM, van Amerongen WE, de Soet JJ. Antimicrobial and buffer capacity of crude extracts of chewing sticks (Miswaki) from Kenya. $J$ Dent Child.

Not addressing 2001;68(3):183-8-152. research question

Hirasawa M, Takada K, Otake S. Inhibition of acid production in dental plaque bacteria by green tea catechins. Caries Res. 2006;40(3):265-270.

Not addressing Kang MS, Oh JS, Kang IC, Hong SJ, Choi CH. Inhibitory effect of methyl gallate and gallic acid on oral bacteria. J. 2008;46(6):744-750. doi:10.1007/s12275008-0235-7. research question

Not addressing research question

Groppo FC, De Cássia Bergamaschi C, Cogo K, Franz-Montan M, Motta RHL, De Andrade ED. Use of phytotherapy in dentistry. Phytother Res.

Not addressing 2008;22(8):993-998. doi:10.1002/ptr.2471. research question Not addressing Market basket. Better Nutrition. 1998;60(11):68-681p. research question Scherer W, Gultz J, Lee SS, Kaim J. The ability of an herbal mouthrinse to reduce gingival bleeding. J Clin Dent. 1998;9(4):97-100. Not addressing research question

Han KC, Wong WC, Benzie IFF. Genoprotective effects of green tea (Camellia sinensis) in human subjects: results of a controlled supplementation trial. $\mathrm{BrJ}$ Nutr. 2011;105(2):171-179. doi:10.1017/S0007114510003211. research question 
Fig. 1: Literature screening procedure (flow-chart)

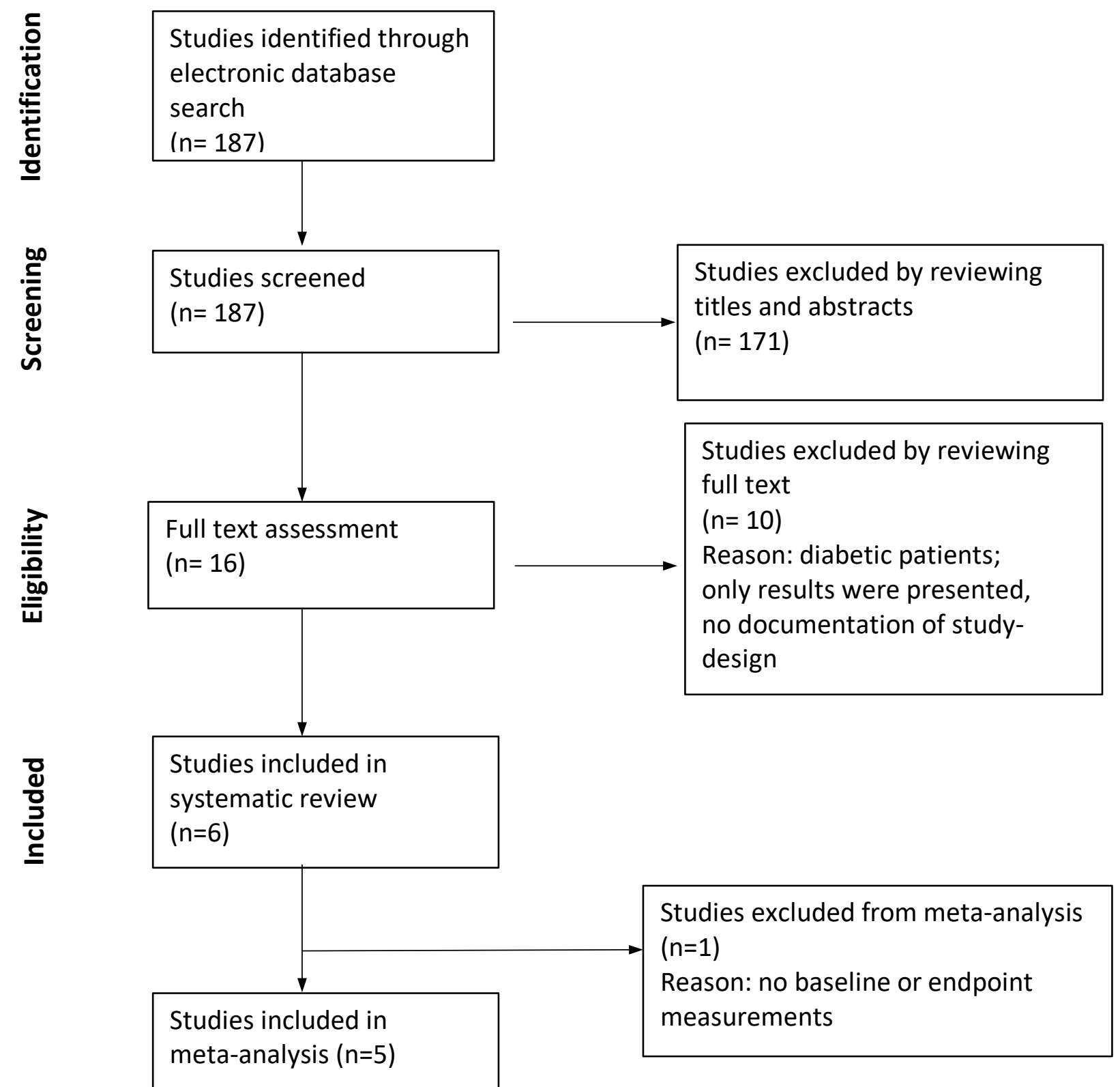


Table 1: Study characteristics of included studies to the review and meta- analysis

\begin{tabular}{|c|c|c|c|c|c|}
\hline $\begin{array}{l}\text { First author } \\
\text { (year of } \\
\text { publication) }\end{array}$ & $\begin{array}{l}\text { Population } \\
\text { characteristics (ethnici- } \\
\text { ty, age, inclusion crite- } \\
\text { ria) }\end{array}$ & $\begin{array}{l}\text { Number } \\
\text { of } \\
\text { subjects }\end{array}$ & $\begin{array}{l}\text { Study design, } \\
\text { Intervention }\end{array}$ & $\begin{array}{l}\text { Green tea characteristics, clinical measure- } \\
\text { ments, study period, oral prophylax- } \\
\text { is/instructions }\end{array}$ & Analyzed parameters \\
\hline Priya (2015) & 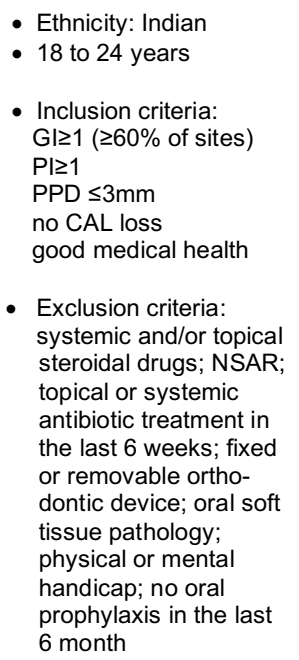 & 30 & $\begin{array}{l}\text { - Study design: } \\
\text { single blinded } \\
\text { randomized controlled trial } \\
\text { - Application: na } \\
\text { - Quantity: na }\end{array}$ & $\begin{array}{l}\text { - Test: } \\
\text { green tea extract made of fragmented leaves } \\
\text { (Camellia sinensis; } 0,5 \mathrm{~g} \text { extract + } 10 \mathrm{ml} \text { dis- } \\
\text { tilled water), } 5 \% \text { Mouthwash solution } \\
\text { - Control: } \\
\mathrm{CHX} 0,2 \% \\
\text { - Clinical measurements: } \\
\text { baseline, } 15 \mathrm{~d}, 28 \mathrm{~d} \text { (endpoint) } \\
\text { - Study period: } \\
28 \mathrm{~d} \\
\text { - Oral prophylaxis/instructions: } \\
\text { modified bass technique }\end{array}$ & $\begin{array}{l}\text { - PI plaque index (Turesky-Gilmore-Glickman, } \\
\text { - Gl gingival Index (Löe and Silness 1963) } \\
\text { - BI bleeding Index (Ainamo \& Bay } \\
\text { - TS Tongue Index (Caydon 2001) } \\
\text { - Stain index (Gründemann et al. 2000) }\end{array}$ \\
\hline $\begin{array}{l}\text { Radafshar } \\
\text { (2017) }\end{array}$ & 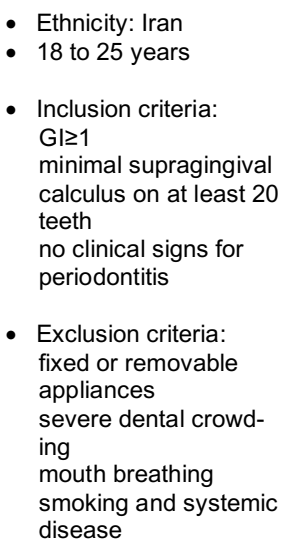 & 40 & $\begin{array}{l}\text { - Study design: } \\
\text { double blinded } \\
\text { randomized clinical controlled } \\
\text { trial } \\
\text { - Application: } \\
\text { rinse twice } 15 \mathrm{~mL} \text { per day } \\
\text { for } 60 \mathrm{~s} \\
1 \mathrm{~h} \text { no coloring drinks after } \\
\text { rinsing }\end{array}$ & $\begin{array}{l}\text { - Test: } \\
\text { green tea extract made of fragmented leaves } \\
\text { of Camellia sinensis, containing } 1 \% \text { of tannin, } \\
\text { Mouthwash solution } \\
\text { - Control: } \\
\mathrm{CHX} 0,12 \% \\
\text { - Clinical measurements: } \\
\text { baseline, } 28 \mathrm{~d} \text { (endpoint) } \\
\text { - Study period: } \\
28 \mathrm{~d} \\
\text { - Oral prophylaxis/instructions: } \\
\text { routine oral hygiene } \\
\text { report of any side effects }\end{array}$ & $\begin{array}{l}\text { PI plaque index (Turesky-Gilmore- } \\
\text { Glickman, 1970) } \\
\text { - Gl gingival Index (Löe and Silness 1963) } \\
\text { - GBI gingival bleeding Index } \\
\text { - side effects }\end{array}$ \\
\hline
\end{tabular}




\begin{tabular}{|c|c|c|c|c|c|}
\hline $\begin{array}{l}\text { First author } \\
\text { (year of } \\
\text { publication) }\end{array}$ & $\begin{array}{l}\text { Population } \\
\text { characteristics (ethnici- } \\
\text { ty, age, inclusion crite- } \\
\text { ria) }\end{array}$ & $\begin{array}{l}\text { Number } \\
\text { of } \\
\text { subjects }\end{array}$ & $\begin{array}{l}\text { Study design, } \\
\text { Intervention }\end{array}$ & $\begin{array}{l}\text { Green tea characteristics, clinical measure- } \\
\text { ments, study period, oral prophylax- } \\
\text { is/instructions }\end{array}$ & Analyzed parameters \\
\hline $\begin{array}{l}\text { Hambire } \\
(2015)\end{array}$ & $\begin{array}{l}\text { - Ethnicity: Indian } \\
\text { - } 9 \text { to } 14 \text { years } \\
\text { - Inclusion criteria: } \\
\text { normal occlusion, ab- } \\
\text { sence of caries and/or } \\
\text { restauration, healthy } \\
\text { periodontium, oral } \\
\text { health } \\
\text { - Exclusion criteria: } \\
\text { history of antibiotics, } \\
\text { topical fluorid treat- } \\
\text { ment with } 4 \text { week prior } \\
\text { to baseline, regular } \\
\text { use of xylitol chewing } \\
\text { gum, tea, coffee, sys- } \\
\text { temic diseases, ortho- } \\
\text { dontic appliances }\end{array}$ & 30 & $\begin{array}{l}\text { - Study design: } \\
\text { double blinded } \\
\text { controlled trial } \\
\text { - Application: } \\
\text { rinse twice a day for } 60 \mathrm{~s} \\
\text { (no quantitiy) } \\
\text { no beverage or food for } 1 \mathrm{~h}\end{array}$ & $\begin{array}{l}\text { - Test: } \\
\text { green tea leaves with mineral water, steeped, } \\
\text { refrigderated. } 0,5 \% \text { solution of green tea } \\
\text { mouthwash } \\
\text { - Control: } \\
\text { CHX 0,2\% } \\
\text { Sodium fluoride } 0,05 \% \\
\text { - Clinical measurements: } \\
\text { baseline, } 14 d \text { (endpoint) } \\
\text { - Study period: } 14 \mathrm{~d} \\
\text { - Oral prophylaxis/instructions: } \\
\text { routine oral hygiene } \\
\text { at baseline professional oral hygiene with } \\
\text { scaling and root planning and polishing }\end{array}$ & $\begin{array}{l}\text { PI plaque index (keine Angabe!) } \\
\text { GI gingival index (keine Angabe!) } \\
\text { Adverse effects by questionnaire } \\
\text { Salivary pH (keine Angabe) }\end{array}$ \\
\hline $\begin{array}{l}\text { Ras- } \\
\text { sameemasma } \\
\text { ung (2013) }\end{array}$ & $\begin{array}{l}\text { - Ethnicity: Thailand } \\
\text { - } 18 \text { to } 55 \text { years } \\
\text { - Inclusion criteria: } \\
\text { patients with gingivitis } \\
>80 \% \text { ppb of VSC } \\
\text { - Exclusion criteria: } \\
\text { systemic complicating } \\
\text { factors, oral mucosal } \\
\text { lesions, smoker, den- } \\
\text { ture wearers, antibiotic } \\
\text { < } 1 \text { month prior to the } \\
\text { study }\end{array}$ & 60 & $\begin{array}{l}\text { - Study design: } \\
\text { double blinded } \\
\text { placebo controlled clinical } \\
\text { trial } \\
\text { - Application: } \\
\text { rinse twice with } 15 \mathrm{~mL} \text { for } \\
60 \text { s daily } \\
30 \mathrm{~min} \text { after no beverage or } \\
\text { food }\end{array}$ & $\begin{array}{l}\text { Test: } \\
\text { green tea hydroalcoholic brownie solution, } \\
\text { contains green tea extract, propylene glycol, } \\
\text { parabenes, Saccharin, mint flavor, } 80 \% \text { of } \\
\text { total catechins } \\
\text { - Control: } \\
\text { placebo (hydroalcoholic brownie solution } \\
\text { of propylene glycol, parabenes, saccharin, } \\
\text { mint flavor) } \\
\text { - Clinical measurements: } \\
\text { baseline, 14d, 28d (endpoint) } \\
\text { - Study period: } \\
28 d \\
\text { - Oral prophylaxis/instructions: } \\
\text { routine oral hygiene, no other mouthwash, } \\
\text { assigned toothbrush and toothpaste }\end{array}$ & $\begin{array}{l}\text { - PI plaque index (Silness\& Löe 1964) } \\
\text { - VSC } \\
\text { - PBI } \\
\text { - adverse effects by questionnaire }\end{array}$ \\
\hline
\end{tabular}




\begin{tabular}{|c|c|c|c|c|c|}
\hline $\begin{array}{l}\text { First author } \\
\text { (year of } \\
\text { publication) }\end{array}$ & $\begin{array}{l}\text { Population } \\
\text { characteristics (ethnici- } \\
\text { ty, age, inclusion crite- } \\
\text { ria) }\end{array}$ & $\begin{array}{l}\text { Number } \\
\text { of } \\
\text { subjects }\end{array}$ & $\begin{array}{l}\text { Study design, } \\
\text { Intervention }\end{array}$ & $\begin{array}{l}\text { Green tea characteristics, clinical measure- } \\
\text { ments, study period, oral prophylax- } \\
\text { is/instructions }\end{array}$ & Analyzed parameters \\
\hline Sarin (2015) & $\begin{array}{l}\text { - Ethnicity: India } \\
\text { - } 18 \text { to } 60 \text { years } \\
\text { - Inclusion criteria: } \\
>20 \text { natural teeth, } \\
\text { mean Pl of at least } 1.5 \text {, } \\
\text { mean } \mathrm{Gl} \text { of at least } \\
1.0, \text { no periodontal } \\
\text { treatment for the last } 3 \\
\text { month } \\
\text { - Exclusion criteria: } \\
\text { periotontal pockets } \\
\geq 5 \mathrm{~mm}, \text { antibiotics } \\
>3 \text { month, antimicrobial } \\
\text { mounthrinse, smooking } \\
\text { habits, periodontal } \\
\text { therapy during the last } \\
3 \text { month }\end{array}$ & 110 & $\begin{array}{l}\text { - Study design: } \\
\text { Triple-blinded, randomized } \\
\text { controlled clinical trial } \\
\text { - Application: } \\
\text { rinse with } 10 \mathrm{~mL} \text { twice a day } \\
\text { for } 30 \text { s }\end{array}$ & $\begin{array}{l}\text { - Test: } \\
\text { extract of leaves of Camellia sinensis, dried, } \\
\text { crushed, brewed to attain required formulation } \\
(2 \%) \text { of green tea mounthrinse } \\
\text { - Control group: } \\
\text { placebo (destilled water coloured and lacked } \\
\text { odor to match green tea mouthrinse) } \\
\text { - Clinical measurements: } \\
\text { baseline, 28d (endpoint) } \\
\text { - Study period: } \\
28 d \\
\text { - Oral prophylaxis/instructions: } \\
\text { NA }\end{array}$ & $\begin{array}{l}\text { - Pl plaque index (Turesky-Gilmore-Glickman, } \\
\text { 1970)) } \\
\text { - GI gingival Index (Loe and Silness 1963) } \\
\text { - adverse effects by questionnaire, no adverse } \\
\text { effects such as irritation, burning sensation, } \\
\text { vesicle formation or mucosal disturbance. }\end{array}$ \\
\hline
\end{tabular}


Table 2a: Results of plaque index / test vs. $\mathrm{CHX}$

\begin{tabular}{|c|c|c|c|c|c|c|}
\hline $\begin{array}{c}\text { Reference } \\
\text { (year of publication) }\end{array}$ & $\begin{array}{c}\mathrm{Pl}_{\text {Test }} \\
\text { Baseline }\end{array}$ & $\mathrm{PI}_{\text {Test }}$ End & $\begin{array}{l}\text { Pl control } \\
\text { Baseline }\end{array}$ & $\begin{array}{l}\text { PI control } \\
\text { End }\end{array}$ & $\begin{array}{c}\text { Intergroup } \\
\Delta \mathrm{PI}_{\text {Test }}\end{array}$ & $\begin{array}{c}\text { Intergroup } \\
\Delta \mathrm{PI}_{\text {control }}\end{array}$ \\
\hline Priya BM (2015) & $2.20 \pm 0.40$ & $1.20 \pm 0.30$ & $2.19 \pm 0.30$ & $1.30 \pm 0.20$ & $1.00 \pm 0.5$ & $0.89 \pm 0.36$ \\
\hline Radafshar (2017) & $1.61 \pm 0.29$ & $1.26 \pm 0.23$ & $1.72 \pm 0.38$ & $1.25 \pm 0.27$ & $0.35 \pm 0.37$ & $0.47 \pm 0.47$ \\
\hline Hambire (2015) & $1.52 \pm 0.04$ & $0.56 \pm 0.40$ & $1.52 \pm 0.05$ & $0.64 \pm 0.46$ & $0.96 \pm 0.40$ & $0.88 \pm 0.46$ \\
\hline
\end{tabular}

Table 2b: Results of plaque index / test vs. placebo

\begin{tabular}{|c|c|c|c|c|c|c|}
\hline $\begin{array}{c}\text { Reference } \\
\text { (year of publication) }\end{array}$ & $\begin{array}{c}\mathbf{P I}_{\text {Test }} \\
\text { Baseline }\end{array}$ & $\mathbf{P I}_{\text {Test }}$ End & $\begin{array}{c}\mathbf{P I}_{\text {control }} \\
\text { Baseline }\end{array}$ & $\begin{array}{c}\mathbf{P I}_{\text {Control }} \\
\text { End }\end{array}$ & $\begin{array}{c}\text { Intergroup } \\
\boldsymbol{\Delta} \text { PI }_{\text {Test }}\end{array}$ & $\begin{array}{c}\text { Intergroup } \\
\boldsymbol{\Delta} \text { PI }_{\text {Control }}\end{array}$ \\
\hline $\begin{array}{c}\text { Rassameemasmaung } \\
\text { (2012) }\end{array}$ & $1.29 \pm 0.30$ & $0.97 \pm 0.24$ & $1.17 \pm 0.27$ & $1.02 \pm 0.25$ & $0.32 \pm 0.38$ & $0.15 \pm 0.36$ \\
\hline Sarin (2015) & $3.43 \pm 0.99$ & $1.77 \pm 0.57$ & $3.59 \pm 1.01$ & $3.46 \pm 1.00$ & $1.66 \pm 1.14$ & $0.13 \pm 1.42$ \\
\hline
\end{tabular}


Table 3a: Results of gingiva index/ test vs. $\mathrm{CHX}$

\begin{tabular}{|c|c|c|c|c|c|c|}
\hline $\begin{array}{c}\text { Reference } \\
\text { (year of publication) }\end{array}$ & $\begin{array}{c}\text { Gl Test }_{\text {Theline }} \\
\text { Basel }\end{array}$ & $\mathrm{GI}_{\text {Test }}$ End & $\begin{array}{l}\text { GIControl } \\
\text { Baseline }\end{array}$ & $\begin{array}{l}\text { Glcontrol } \\
\text { End }\end{array}$ & $\begin{array}{c}\text { Intergroup } \\
\Delta \mathrm{Gl}_{\text {Test }}\end{array}$ & $\begin{array}{r}\text { Intergroup } \\
\Delta \text { GI }\end{array}$ \\
\hline Priya BM (2015) & $2.01 \pm 0.40$ & $1.43 \pm 0.40$ & $2.06 \pm 0.10$ & $1.53 \pm 0.20$ & $0.58 \pm 0.57$ & $0.53 \pm 0.22$ \\
\hline Radafshar (2017) & $1.47 \pm 0.14$ & $1.16 \pm 0.11$ & $1.41 \pm 0.10$ & $1.14 \pm 0.09$ & $0.31 \pm 0.18$ & $0.30 \pm 0.13$ \\
\hline Hambire (2015) & $2.34 \pm 0.65$ & $1.10 \pm 0.50$ & $2.68 \pm 1.00$ & $1.17 \pm 0.45$ & $1.24 \pm 0.82$ & $1.51 \pm 1.09$ \\
\hline
\end{tabular}

Table 3b: Results of gingiva index/ test vs. placebo

\begin{tabular}{|c|c|c|c|c|c|c|}
\hline $\begin{array}{c}\text { Reference } \\
\text { (year of publication) }\end{array}$ & $\begin{array}{c}\text { GlTest } \\
\text { Baseline }\end{array}$ & GI $_{\text {Test }}$ End & $\begin{array}{l}\text { Glcontrol } \\
\text { Baseline }\end{array}$ & $\begin{array}{l}\text { GlControl } \\
\text { End }\end{array}$ & $\begin{array}{c}\text { Intergroup } \\
\Delta \mathrm{Gl}_{\text {Test }}\end{array}$ & $\begin{array}{l}\text { Intergroup } \\
\Delta \text { Glcontrol }\end{array}$ \\
\hline $\begin{array}{l}\text { Rassameemasmaung } \\
\text { (2012) }\end{array}$ & $0.84 \pm 0.24$ & $0.76 \pm 0.25$ & $0.82 \pm 0.35$ & $0.73 \pm 0.29$ & $0.08 \pm 0.35$ & $0.09 \pm 0.45$ \\
\hline Sarin (2015) & $1.50 \pm 0.34$ & $0.82 \pm 0.24$ & $1.47 \pm 0.30$ & $1.42 \pm 0.35$ & $0.68 \pm 0.42$ & $0.05 \pm 46$ \\
\hline
\end{tabular}


Table 4 a. Meta-analysis PI Test vs. CHX: Endpoint

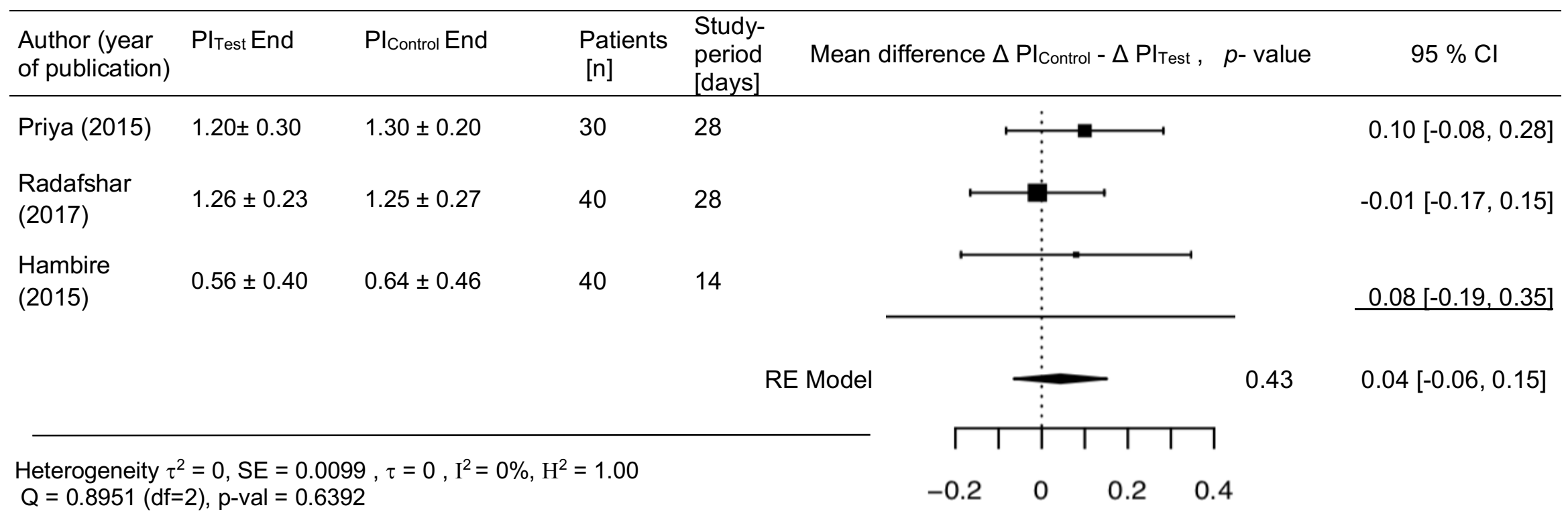

Observed Outcome 
Table 4 b. Meta-analysis PI Test vs, CHX: Change

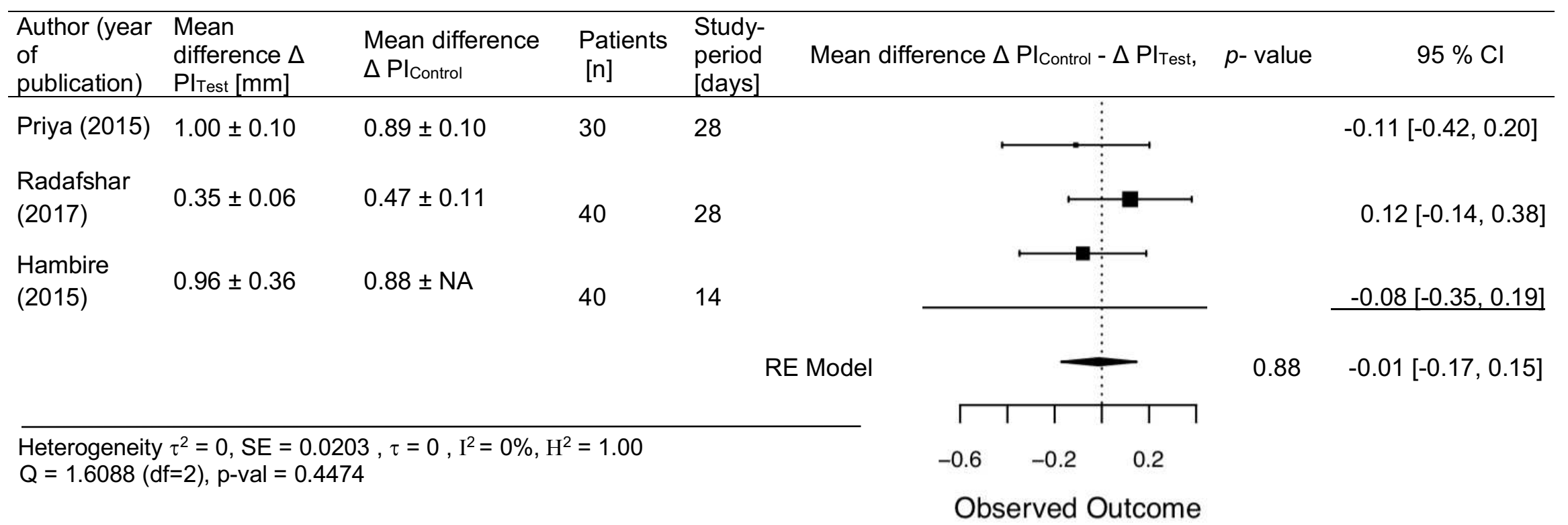


Table 4c. Meta-analysis PI Test vs, Placebo: Endpoint

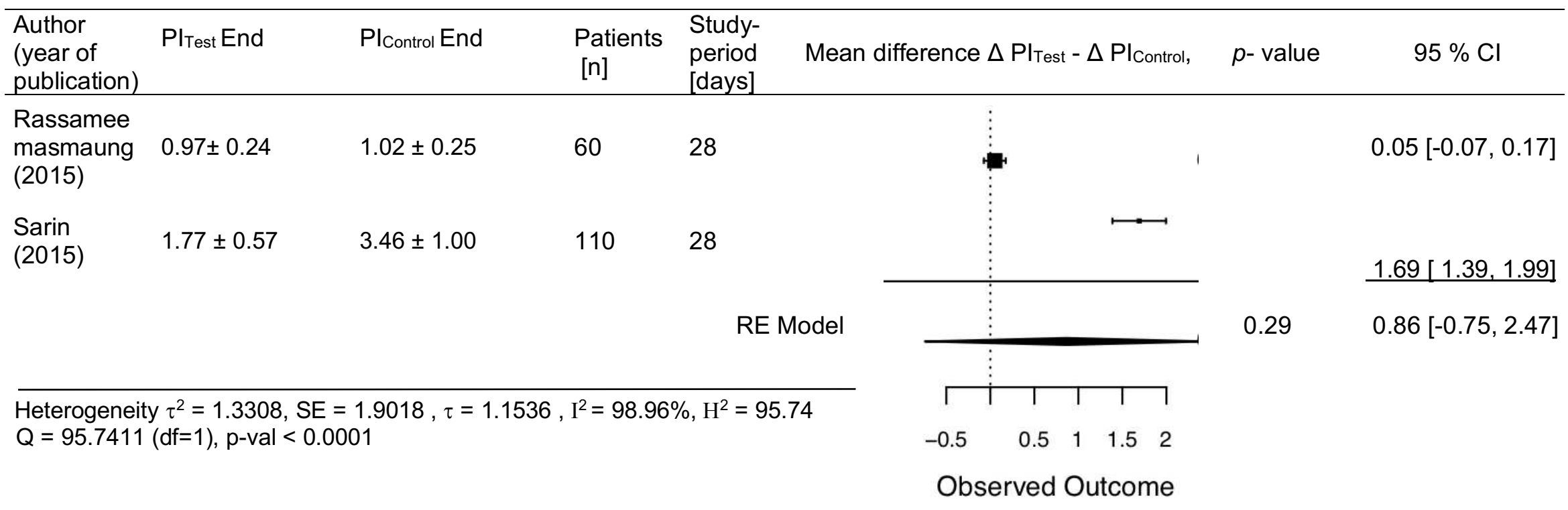


Table 4d. Meta-analysis PI Test vs, Placebo: Change

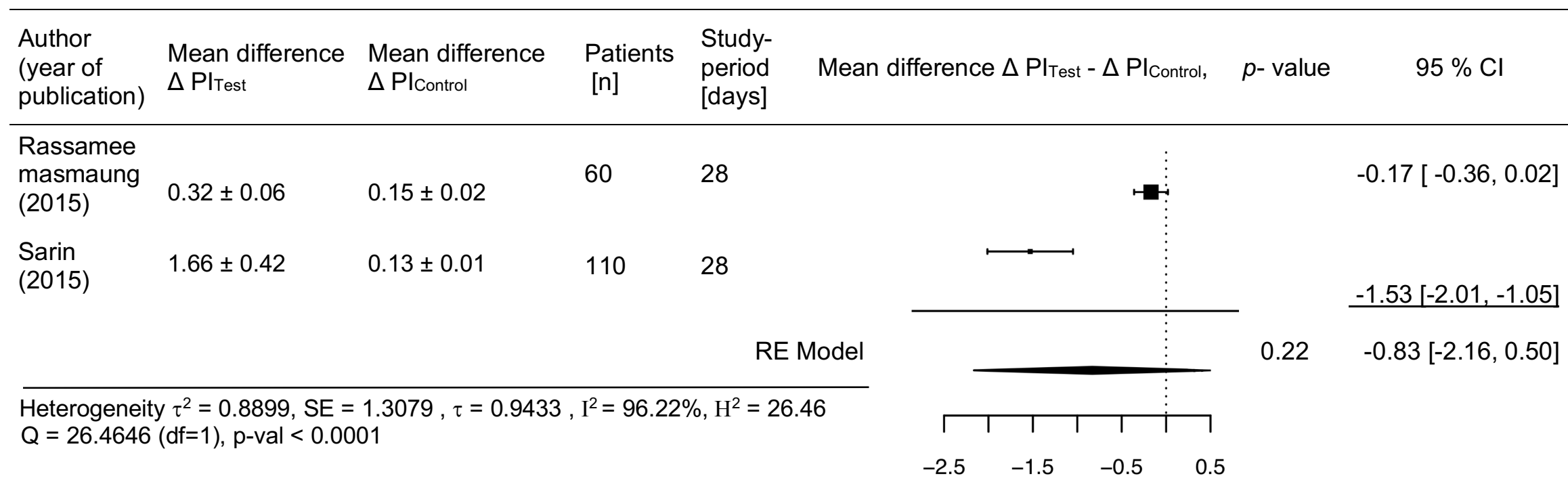


Table 5a. Meta-analysis GI Test vs, CHX: Endpoint

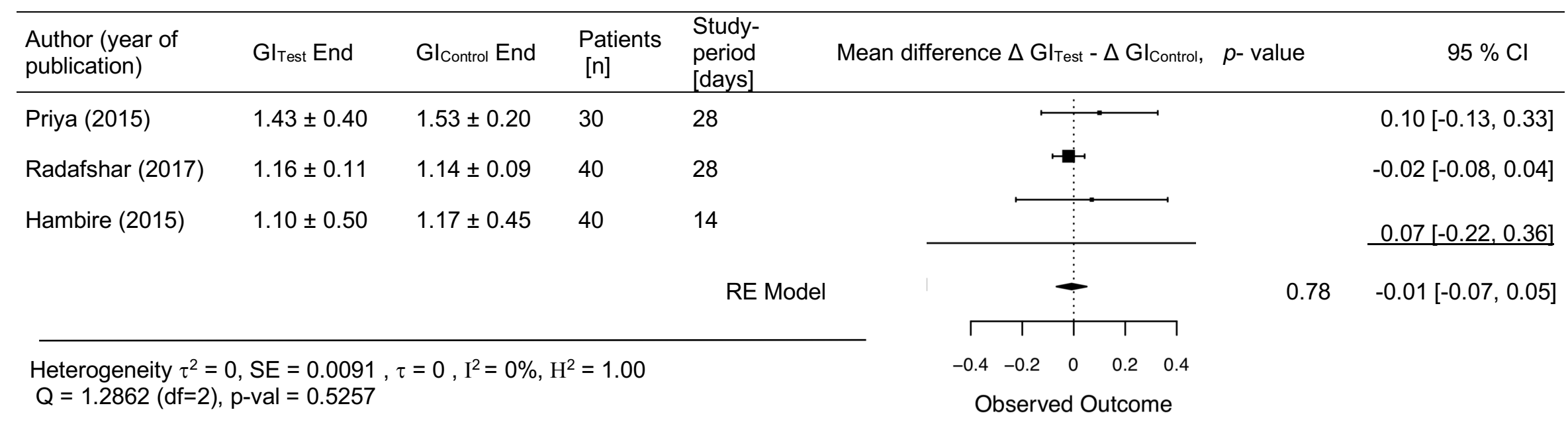


Table 5b. Meta-analysis GI Test vs, CHX: Change

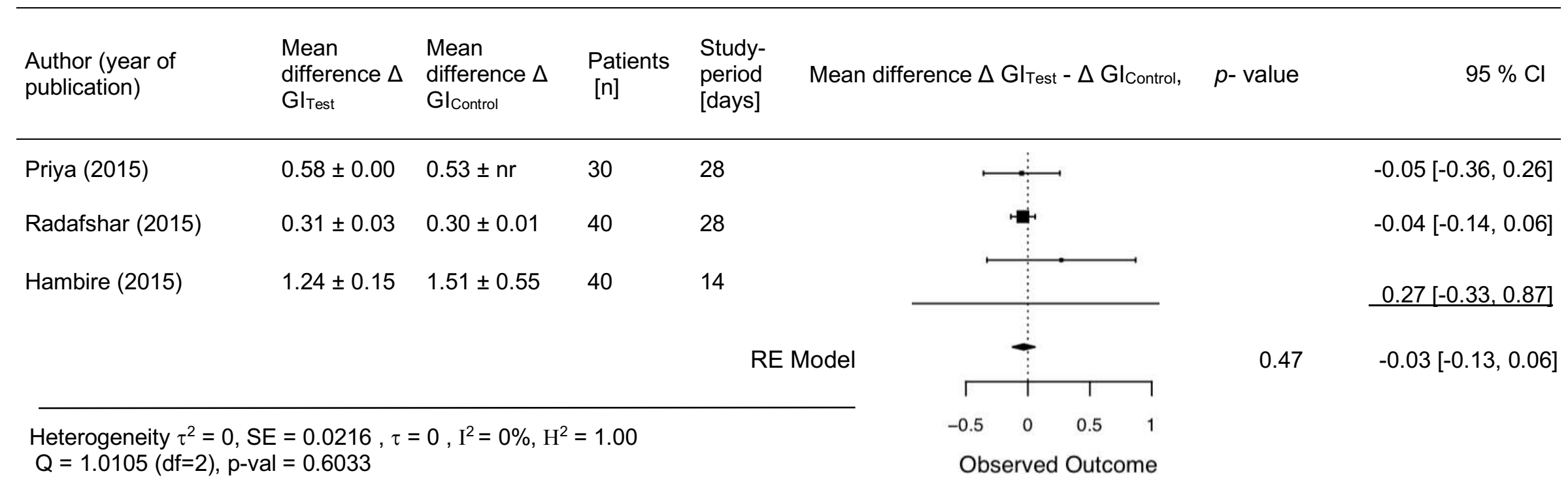


Table 5c. Meta-analysis GI Test vs, Placebo: Endpoint

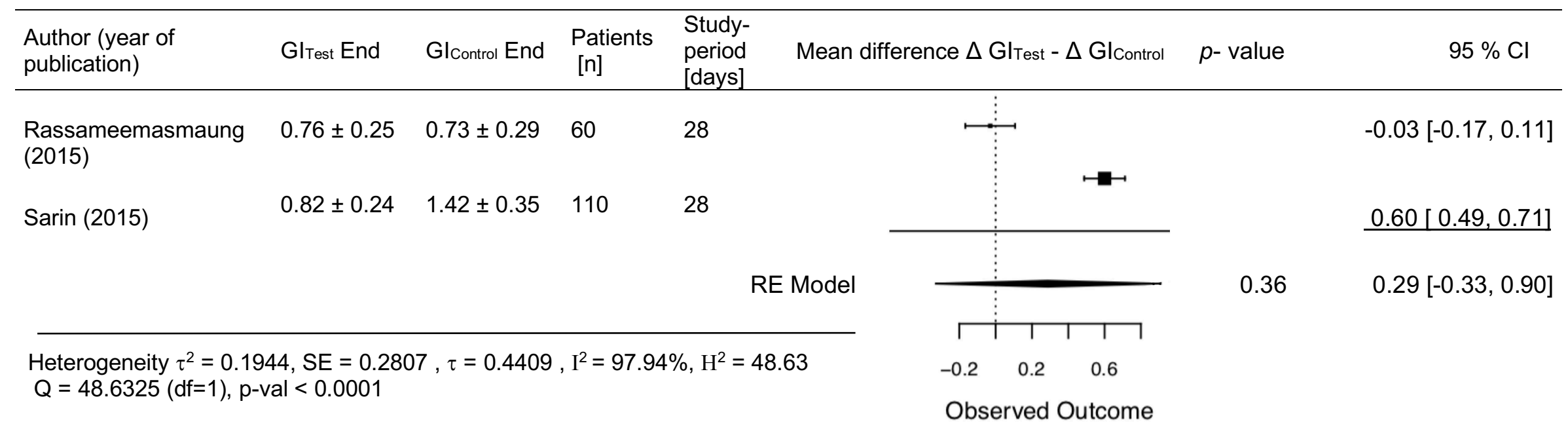


Table 5d. Meta-analysis GI Test vs, Placebo: Change

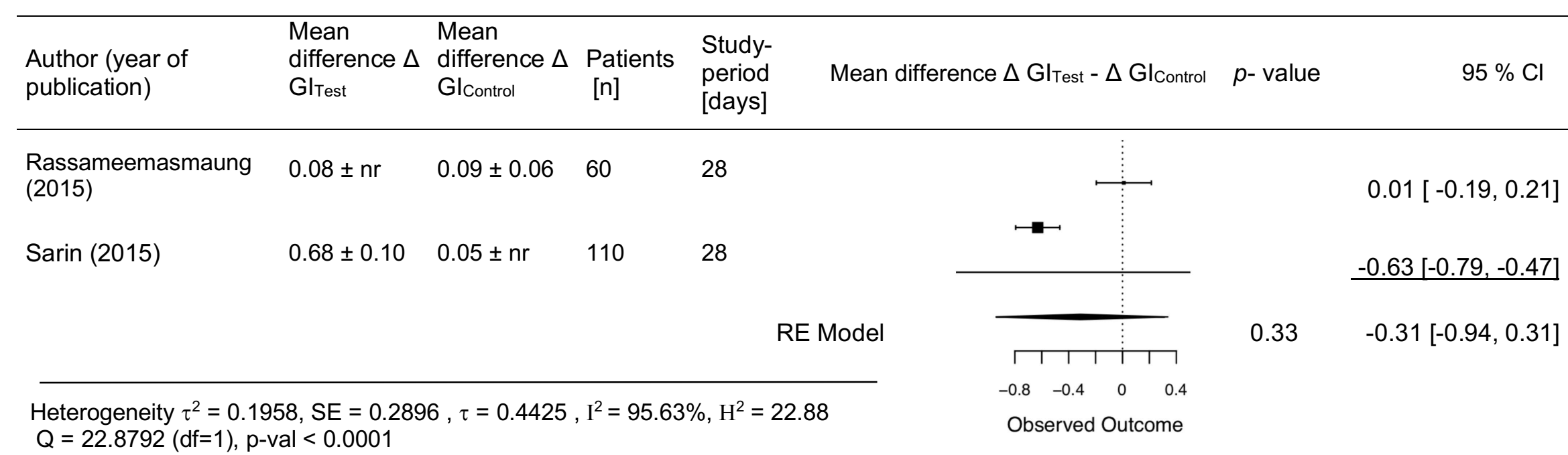


PRISMA Checklist

\begin{tabular}{|c|c|c|c|}
\hline$\overline{\text { Section/topic }}$ & 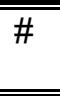 & Checklist item & $\begin{array}{l}\text { Reported } \\
\text { on page \# }\end{array}$ \\
\hline \multicolumn{4}{|l|}{ TITLE } \\
\hline Title & 1 & $\begin{array}{l}\text { Identify the report as a systematic review, meta-analysis, or } \\
\text { both. }\end{array}$ & 1 \\
\hline \multicolumn{4}{|l|}{$\overline{\text { ABSTRACT }}$} \\
\hline $\begin{array}{l}\text { Structured } \\
\text { summary }\end{array}$ & 2 & $\begin{array}{l}\text { Provide a structured summary including, as applicable: } \\
\text { background; objectives; data sources; study eligibility criteria, } \\
\text { participants, and interventions; study appraisal and synthesis } \\
\text { methods; results; limitations; conclusions and } \\
\text { implications of key findings; systematic review registration } \\
\text { number. }\end{array}$ & 2 \\
\hline \multicolumn{4}{|l|}{ INTRODUCTION } \\
\hline Rationale & 3 & $\begin{array}{l}\text { Describe the rationale for the review in the context of what is } \\
\text { already known. }\end{array}$ & 4,5 \\
\hline Objectives & 4 & $\begin{array}{l}\text { Provide an explicit statement of questions being addressed } \\
\text { with reference to participants, interventions, comparisons, } \\
\text { outcomes, and study design (PICOS). }\end{array}$ & 6 \\
\hline \multicolumn{4}{|l|}{ METHODS } \\
\hline $\begin{array}{l}\text { Protocol and } \\
\text { registration }\end{array}$ & 5 & $\begin{array}{l}\text { Indicate if a review protocol exists, if and where it can be } \\
\text { accessed (e.g., Web address), and, if available, provide } \\
\text { registration information including registration number. }\end{array}$ & 5 \\
\hline Eligibility criteria & 6 & $\begin{array}{l}\text { Specify study characteristics (e.g., PICOS, length of follow-up) } \\
\text { and report characteristics (e.g., years considered, language, } \\
\text { publication status) used as criteria for eligibility, giving } \\
\text { rationale. }\end{array}$ & 6 \\
\hline $\begin{array}{l}\text { Information } \\
\text { sources }\end{array}$ & 7 & $\begin{array}{l}\text { Describe all information sources (e.g., databases with dates of } \\
\text { coverage, contact with study authors to identify additional } \\
\text { studies) in the search and date last searched. }\end{array}$ & 6 \\
\hline Search & 8 & $\begin{array}{l}\text { Present full electronic search strategy for at least one } \\
\text { database, including any limits used, such that it could be } \\
\text { repeated. }\end{array}$ & 6 \\
\hline Study selection & 9 & $\begin{array}{l}\text { State the process for selecting studies (i.e., screening, } \\
\text { eligibility, included in systematic review, and, if applicable, }\end{array}$ & 6,7 \\
\hline $\begin{array}{l}\text { Data collection } \\
\text { process }\end{array}$ & 10 & $\begin{array}{l}\text { included in the meta-analysis). } \\
\text { Describe method of data extraction from reports (e.g., piloted } \\
\text { forms, independently, in duplicate) and any processes } \\
\text { for obtaining and confirming data from investigators. }\end{array}$ & 7 \\
\hline Data items & 11 & $\begin{array}{l}\text { List and define all variables for which data were sought (e.g., } \\
\text { PICOS, funding sources) and any assumptions and } \\
\text { simplifications made. }\end{array}$ & 7,8 \\
\hline $\begin{array}{l}\text { Risk of bias in } \\
\text { individual studies }\end{array}$ & 12 & $\begin{array}{l}\text { Describe methods used for assessing risk of bias of individual } \\
\text { studies (including specification of whether this was } \\
\text { done at the study or outcome level), and how this information } \\
\text { is to be used in any data synthesis. }\end{array}$ & 7 \\
\hline $\begin{array}{l}\text { Summary } \\
\text { measures }\end{array}$ & 13 & $\begin{array}{l}\text { State the principal summary measures (e.g., risk ratio, } \\
\text { difference in means). }\end{array}$ & 7 \\
\hline $\begin{array}{l}\text { Synthesis of } \\
\text { results }\end{array}$ & 14 & $\begin{array}{l}\text { describe the methods of handling data and combining results } \\
\text { of studies, if done, including measures of consistency }\left(e . g ., I^{2}\right)\end{array}$ & 7,8 \\
\hline $\begin{array}{l}\text { Risk of bias } \\
\text { across studies }\end{array}$ & 15 & $\begin{array}{l}\text { for each meta-analysis. } \\
\text { Specify any assessment of risk of bias that may affect the } \\
\text { cumulative evidence (e.g., publication bias, selective } \\
\text { reporting within studies). }\end{array}$ & 7 \\
\hline $\begin{array}{l}\text { Additional } \\
\text { analyses }\end{array}$ & 16 & $\begin{array}{l}\text { Describe methods of additional analyses (e.g., sensitivity or } \\
\text { subgroup analyses, meta-regression), if done, indicating which } \\
\text { were pre-specified. }\end{array}$ & 7,8 \\
\hline
\end{tabular}

